\title{
Forests, Biomass Use and Poverty in Malawi
}

\section{Draft Background Paper for the Malawi Poverty Assessment}

\author{
Sushenjit Bandyopadhyay ${ }^{1}$, Priya Shyamsundar, ${ }^{1}$ Alessandro Baccini
}

\begin{abstract}
In this paper, we seek to answer three sets of questions about poverty and forests in Malawi: a) What is the extent of biomass available for meeting the energy needs of the poor in Malawi and how is this distributed? b) To what extent does fuelwood scarcity affect the welfare of the poor? c) How do households cope with scarcity? In particular, do households spend more time in fuelwood collection and less time in agriculture in response to scarcity? We attempt to answer these questions using household and remote-sensing data. We find that 80 percent of rural poor households in Malawi are likely to benefit from an increase in biomass per hectare in their community. Rural women respond to biomass scarcity by increasing the time they spend on fuelwood collection. However, the actual decrease in consumption expenditure and increase in time in fuelwood collection are small and biomass scarcity is not associated with a reduction in agricultural labor supply.
\end{abstract}

Key Words: Deforestation, Fuelwood, Poverty, Labor Allocation

\begin{abstract}
World Bank Policy Research Working Paper 4068, November 2006
The Policy Research Working Paper Series disseminates the findings of work in progress to encourage the exchange of ideas about development issues. An objective of the series is to get the findings out quickly, even if the presentations are less than fully polished. The papers carry the names of the authors and should be cited accordingly. The findings, interpretations, and conclusions expressed in this paper are entirely those of the authors. They do not necessarily represent the view of the World Bank, its Executive Directors, or the countries they represent. Policy Research Working Papers are available online at http://econ.worldbank.org.
\end{abstract}

\footnotetext{
${ }^{1}$ Policy and Economics Team, Environment Department, World Bank. We would like to thank Kirk Hamilton, Peter Dewees, Kenneth Chomitz and Antonio Nucifora for their careful comments, Kathleen Beegle and other colleagues from DEC for their advice, and National Statistical Office, Malawi for providing us with the data from the second integrated household survey (IHS2). We are grateful to the Swedish International Development Cooperation Agency for their financial support for this work.
} 


\section{Introduction}

Malawi is one of the poorest countries in Africa. Three-fifths of the population is poor and unable to meet their daily needs. Life expectancy is very low and declining as Malawians struggle with HIV/AIDs as well as other traditional diseases (Mukherjee and Benson 2003). While poverty is highest in the southern part of the country, rich and poor districts are found all over (IFPRI 2000). With a mean per capita income of $\$ 170$ in 2004, poverty reduction is of central concern to policy makers (WDI 2005).

Poverty and forest degradation appear to go hand in hand in Malawi. Forest degradation by all accounts is rampant. A third of Malawi is considered forested, but these patchy forests have been declining at a rapid rate. Between 1990 and 2000, the area under forest cover in Malawi decreased at a rate ranging from $1 \%$ to $2.6 \%$ per annum (FAO 2005, WRI 2003). ${ }^{2}$ In a country where $90 \%$ of the poor live in rural areas and share space with and use forests and shrub lands, it is not surprising that many express concern about the effect of poverty on the environment. ${ }^{3}$

Loss of forest cover in Malawi is attributed to agricultural expansion, biomass use for fuelwood, charcoal production and a number of other factors including tobacco curing, brick burning and so on (Malawi SDNP 1998, Minde et al. 2001). While land under agriculture in Malawi increased by some 31\% between 1972 and 1990 (Eschweiler 1993), this type of expansion has apparently slowed in recent years because of the limited supply of cultivable land. Over 90 percent of total energy demand in Malawi is met by biomass. With population growth in Malawi being one of the highest in Southern Africa, this demand is considered a serious threat to forests (Malawi SDNP 1998).

There is currently considerable policy interest in Malawi on the nexus between poverty and biomass scarcity. To cite a recent newspaper article, "Environmental degradation and poverty alleviation are urgent national issues that have a lot in common, but are often treated separately” (Davie Mkwambisi, 20 January 2006, Opinion, Malawi Nation). This paper focuses on a subset of questions that seem to be driving this kind of concern: a) What is the extent of biomass available for meeting the energy needs of the poor in Malawi and how is this distributed? b) To what extent are poverty and forest degradation inter-linked and what factors affect this

\footnotetext{
${ }^{2}$ Estimates of deforestation in Malawi done by different global organizations differ.

${ }^{3}$ Note a recent New York Times articles (Nov, 1, 2005) by Michael Wines entitled "Malawi is Burning and Deforestation Erodes Economy.”
} 
relationship? c) How do households cope with scarcity? In particular, do women and men spend more time in fuelwood collection activities and less time in agriculture in response to scarcity? We attempt to answer these questions using household data from a nation-wide survey in Malawi. We also use satellite data to assess biomass scarcity in Malawi and link the satellite images to household fuelwood use.

While there is a generally accepted notion in many parts of the world that fuelwood demand contributes to forest degradation, the impact of wood fuel harvesting on wood resources and forest health is actually not straightforward. Forest degradation can occur as a result of unsustainable use of fuelwood to meet livelihood needs. For example, Barnes et al. (2001) show through a 46 country based study that widespread tree removal and forest depletion around urban areas can occur as urban energy demand grows. But this demand slows as cities get wealthier.

The extent to which fuelwood harvesting contributes to deforestation or degradation depends on factors such as source of demand and supply, nature of fuelwood and charcoal markets and household practices (Arnold et al. 2003). Fuelwood scarcity need not contribute to deforestation as long as entire trees and root stock are not destroyed. In fact, as Dewees (1989) argues, when harvesting involves hacking of branches and collection of dead wood, this can lead to increased productivity of woodland areas.

In the case of Malawi, there is both evidence of deforestation and concern about the implications for fuelwood availability (Walker 2004, Malawi SDNP 1998). A useful question to ask is what feeds this concern. Is it simply a reflection of long-standing global environmental worries related to the gap between fuelwood supply and demand, which is echoed by Malawian officials (Dewees 1995, Walker 2004)? Or, is fuelwood scarcity sufficiently high that it affects household well being? Physical scarcity of wood fuel does not always mean that households perceive it to be scarce. Whether wood fuel is economically scarce will depend on household constraints and whether and how they are able to respond to physical scarcity (Dewees 1989, 1995). Farmers in Malawi do seem to consider fuelwood scarcity a problem. In a recent paper by Walker (2004), 92\% of the farmers he interviewed in Southern Malawi were aware of decreasing tree availability and 94 to $100 \%$ of them expected this to cause problems for meeting future needs.

Fuelwood scarcity in Malawi can affect household welfare in different ways. Poor households in particular may not have access to alternate energy resources and may increase the time spent on 
fuelwood collection, reducing time on productive activities, leisure or household care. This type of indirect but important relationship between resource collection efforts and welfare is identified in a recent dissertation by Nankuni (2004). She finds that stunting in children in Malawi is associated with the long periods of time spent by women in collecting water. Thus, under circumstances where markets are lean, increasing resource scarcity can force households to reallocate labor and thereby reduce welfare.

There are other ways in which fuelwood scarcity can affect household well-being. Households may reduce their use of energy and switch to lower quality wood (Brouwer et al. 1997). This may limit their ability to cook or light their homes. More generally, forest cover losses can also reduce the availability of other forest products such as fruit, mushroom, poles, bush meat etc, and can have long-run effects on local hydrological services and agricultural output.

In this paper, we test the hypothesis that biomass scarcity in Malawi has a 'net' negative effect on household welfare. We test this hypothesis for different regions in the country and for rich and poor households. In a recent paper, Monica Fisher (2004), studying three villages in southern Malawi, shows that forests can prevent poverty by supplementing income and may even help raise standards of living. Our work focuses on biomass availability and asks similar questions using country-wide data.

Households of course engage in efforts to 'manage' biomass scarcity. From a practical and policy perspective, it is important to understand how households respond to fuelwood depletion. Households cope with scarcity in many ways: some plant trees, others increase the time allocated to collection, and still others decrease consumption or change cooking practices. Strategies may include improvements in fire management practices, sharing fires for cooking, preparation of fewer meals or changes in diet favoring fast-cooking (Dewees 1989).

For households the issue of biomass scarcity is a dynamic optimization problem of the renewable natural resource. That is, in each period a household decides how much biomass stock to consume and how much to leave for the future. The revealed preference of the households indicates that households in Malawi have depleted their biomass stock over the years. This may be because of high discount rates of the poor households. 
A qualification related to our analyses is that cross section data only shows a static snap-shot of the revealed preferences of all households. This static analysis cannot cast any light on the dynamics of biomass depletion and the rationale of the households for doing so. Thus, the picture we present below highlight the state of the equilibrium at a given point in time. This picture, though incomplete, adds valuable insight to the present conditions of the households and their relationship with biomass scarcity.

In this paper, our focus is on the increase in time spent on collecting fuelwood, which is a frequent and important response to biomass scarcity (Cooke 1998a, 1998b, Kumar and Hotchkiss 1988, Dewees 1989). Fisher et al. (2005) show that households in Malawi increase labor allocated to forest extraction as returns to these activities increase. They argue that with increasing wood scarcity, the returns to forest labor and time allocated to forest product extraction are likely to increase. As elsewhere, Malawian households use other coping strategies as well: they switch to lower quality wood, economize on wood use and increase the number of collectors (Brouwer et al. 1997). In this paper, we use this broad understanding of household responses to fuelwood scarcity to carefully examine how forest-dependent households allocate labor. We focus on time spent on fuelwood collection and ask whether scarcity has an effect on collection time and on labor allocated to agricultural tasks.

The paper makes two contributions to the literature on forests and poverty. First, there are few studies that combine spatial information with household data (Dasgupta 2005). Most existing studies that focus on degradation and household behavior use fuelwood prices or other selfreported measures of scarcity (Cooke 1998b). By linking biophysical data with household data, we think we are making a significant contribution to existing literature. Second, we try to examine the poverty-environment nexus at three levels: a) the district level to understand the distribution of biomass availability; b) at the household level to assess welfare implications of biomass scarcity; and c) at the individual level to examine responses to scarcity. By taking a three-tier approach, we try to provide a broad and simultaneously nuanced understanding of the complex interactions between forests and the poor. Further, our paper uses a large-scale survey to quantify the impacts of biomass scarcity on poverty in Malawi. Policy makers in Malawi have been struggling with deforestation and fuelwood loss for decades. We hope our analyses can point to the extent of the problem in welfare terms and its regional manifestations. 
In the following sections, we first discuss the data used to assess biomass availability and household behavior. Section 3 presents the methods used. Section 4 is the results section that includes a description of biomass availability and fuelwood use; an analysis of the determinants of household welfare and the role played by fuelwood scarcity; and coping strategies and women's labor allocation. Section 5 presents conclusions.

\section{DATA}

Our main interest in this paper is to understand household dependence on biomass for energy and see how scarcity may affect household welfare. In order to understand the relationship between poverty and fuelwood use, we estimate biomass availability in Malawi based on satellite data. We combine these estimations with household level data from a recent household survey.

\section{$\underline{\text { Remote Sensing and Biomass Data }}$}

Several sets of remotely sensed data were used to estimate biomass distribution in Malawi. The first is 8 days composite data recorded by the Moderate Resolution Imaging Spectroradiometer (MODIS) that are atmospherically corrected and cloud cleared. ${ }^{4}$ These data, which provide average surface reflectance over 8 days with a spatial resolution of 463.3 meters, are used to map the amount and spatial distribution of standing biomass at the year 2004. The second is a set of Orthorectified Landsat Thematic Mapper (TM) and Enhanced Thematic Mapper (ETM) data for the year circa 1990 and circa 2000 respectively. ${ }^{5}$ These data provide surface reflectance at the resolution of 30 meters and are used to accurately identify training samples for the estimated biomass model. The MODIS Continuous Field of View (MOD44B) product provides information on vegetation density and is used to separate forested land from areas of non-forest. Elevation information for Malawi is extracted from the Global Digital Elevation Model (GTOPO30) with a horizontal grid spacing of 30 arc seconds (about $1 \mathrm{~km}$ ). ${ }^{6}$

In order to estimate biomass at the year 2004, we need to identify the relationship between remotely sensed data and biomass. For this purpose, we use a study undertaken by the Ministry of Forests and Natural Resources, Government of Malawi in 1993: Forest Resources Mapping and Biomass Assessment for Malawi. The report provides detailed land cover maps for Malawi

\footnotetext{
${ }^{4}$ MODIS data are available at http://delenn.gsfc.nasa.gov/ imswww/pub/imswelcome/

${ }^{5}$ Landsat images are available at http://www.landsat.org/

${ }^{6}$ GTOPO30 was developed at the U.S. Geological Survey's Center for Earth Resources Observation and Science (EROS).
} 
derived from visual interpretation of Landsat remotely sensed data. The land cover maps describe land cover status in 1990 and 1970 and provide a comparison of changes over this period. Based on field surveys, the report estimates total biomass and average biomass volume per hectare for different land cover classes at the district and regional level. ${ }^{7}$ We use the data available in this report to help us model the relationship between biomass and remotely-sensed data.

\section{$\underline{\text { Household data }}$}

The household data used in this analysis comes from the second integrated household survey (IHS2). The IHS2 was a comprehensive socio-economic survey of living standards in Malawi. The National Statistics Office administered the IHS2 household questionnaires to 11,280 households from 564 rural and urban enumeration areas between March 2004 and April 2005. This paper focuses on the data from the 492 rural enumeration areas, covering 9,840 households. Together with the household data the survey also collected community level information from each of the enumeration areas.

The nationally representative data is divided into three rural regions of North, Center, and South. We further divide the regions into eight agricultural development district (ADD) zones. These are: Karonga, Mzuzu, Kasungu, Salima, Lilongwe, Machinga, Blanyre, and Ngabu.

The community level data includes, among other things, information about access to basic services such as distances to asphalt road, daily, weekly and ADMARK markets, post office, banks, urban centers, Boma, and other resources. ${ }^{8}$ The data on the economic activities at the community level contain information about three important sources of income. The various sources of income include agriculture and fishing as well as use of fuelwood and charcoal. The summary statistics for the community indicators are in Table 1.

The data on the fuelwood collection, its use and source are in the household part of the survey. Availability of alternative to fuelwood collection is measured by indicators if the household used

\footnotetext{
${ }^{7}$ Because one of the goals of the project was also to characterize the land cover classes in terms of woody biomass, defined as "the volume of trees including bark from ground to top including branches with a diameter above 2 centimeters over bark" the project carried out a biomass assessment in the evergreen forest, Brachystegia forest in hilly and flat areas, in intensive agriculture land and, in extensive agriculture in forested land.

${ }^{8} \mathrm{~A}$ Boma is a local administrative headquarter. The ADMARK market stands for agricultural input market established by Agricultural Development and Marketing Corporation.
} 
other cooking fuels or purchases fuelwood. The household level of welfare is measured by the real annual per capita consumption expenditure of the household. The agricultural characteristics of the household are represented by the households that reported agriculture as the main economic activity and the household that grew tobacco in the last growing season. Area under rain-fed and dry (dimba) agriculture cultivated by the household, area owned but not cultivated by the household, area with trees owned by the household were also taken into account.

A third type of data collected by the survey relates to individual members of a household. Along with demographic characteristics of the members such as age, sex, marital status, the survey collected data on the amount of time spent by each household member above five years in various domestic and productive activities. These activities include fuelwood collection and household agriculture.

We define active men and women as those ten years and above who reported time spent on at least one of the activities for which time use data was collected. We also looked at children between age five and ten. However, preliminary analysis showed that very few children below age ten participated in fuelwood collection and agricultural production. Thus, by considering men and women above age ten we take into account most of the active labor force in the household.

We separate the households living in areas with less than 20 cubic meters per hectare of biomass (Less) and in areas with more than 20 cubic meters per hectare of biomass (More). The areas with less than 20 cubic meters per hectare of biomass are where biomass is scarce and areas with more biomass are where the scarcity is not as severe. Sixty five percent of the rural households surveyed reside in biomass scarce areas.

Along with the labor allocation data for the active men and women, we control for the following demographic characteristics: age, marital status of the active person, number of living children less than five years old, if the active person suffered from any illness or injury in the past two weeks, if the active person suffered from any chronic illnesses, and the number of other members of the households suffering from chronic illnesses.

\section{Methods}

\section{Biomass Assessment}


Optical remote sensing measurements reflect the interaction between radiation and forest canopies and are influenced by the canopy's structural properties. For this reason remote sensing data have been extensively used to map land cover and forest structural variables such as forest density and timber volume (Franklin 1986, Cohen 1992, Puhr 2000). Remote sensing also has the potential for providing spatial and temporal information on biomass availability because forest characteristics such as crown size and forest density are correlated with biomass (Shugart 2000, Franklin 1986). New techniques and the availability of remotely sensed data with higher radiometric and spatial characteristics such as MODIS, now make it possible to assess biomass availability at the regional and local scale (Baccini et al. 2004).

In this study, we derive biomass estimates for the year 2004 by applying a regression tree algorithm to identify the relationship between the output variable, biomass, and two predictors: remotely sensed data and elevation. Tree-based models have been previously used to predict both categorical (Friedl 1997) and continuous variables (Michaelsen 1994). ${ }^{9}$ The basic theory behind such models is reported in Breiman (1984). ${ }^{10}$ For the work reported here, the specific methodology is referred to as a regression tree, because the model is predicting a continuousvalued response variable.

The regression tree is a supervised algorithm that uses a set of examples to identify the relationship between the regressor (biomass) and the predictors. In order to identify examples to train the algorithm, 1990 Landsat data similar to the ones used in the Department of Forestry, Government of Malawi, report (GOM 1993) were first analyzed. Regions with vegetation formations were selected from the Landsat 1990 scenes and then compared with the scenes for the year 2000 to verify that no changes occurred within the area selected. If changes occurred the sample was discarded. A last check was then performed using MODIS 500 meters data for the

\footnotetext{
${ }^{9}$ A variety of techniques are used to classify vegetation and forest structure from satellite data. Unsupervised clustering algorithms and parametric supervised algorithms such as the maximum likelihood algorithms are the most commonly used methods. Vegetation structures such as forest canopy density and above ground forest biomass are commonly analyzed using linear statistical models based on ordinary least squares. These methods present limitations when the dependent and predictor variables are not linearly related, or when the predictors include high-dimensional input data. Further, multi-collinearity among the regressor variables can result in misleading inferences. Alternative methods such as neural networks and tree based-models overcome these limitations, and have been shown to be efficient in dealing with complex non-linear relationships (Friedl 1997, Gopal 1998).

${ }^{10}$ Tree-based models (1) make no assumptions regarding the distributional properties of the input data, (2) are able to capture nonlinear relationships between the response and predictor variables, (3) and provide easily understandable outputs.
} 
year 2004. If there was no discrepancy between the Landsat data for the year 2000 and the MODIS data for the year 2004, the area was selected as training area. ${ }^{11}$ For each training area, the spectral reflectance derived from MODIS 500 meters and the elevation data were extracted and used for the training of the algorithm. During this phase the algorithm identifies the relationships between above ground forest biomass and the predictors (remotely sensed and elevation data). Once the relationships are defined, they were applied to the entire set of 2004 data to predict forest biomass for the area where remotely sensed and elevation data were available.

An important step in assessing biomass is to define and identify areas as forests and non-forests.

To separate forested from non-forested areas, we use a MODIS product called MOD44B (Vegetation Continuous Field) that provides information on the density of the vegetation defined as ground cover from 0 to $100 \%$. The combined visual analysis of the vegetation density product with the high resolution Landsat data indicates that a threshold of $20 \%$ best separates forested from non-forested land. We estimate the amount of forest area in Malawi as areas with vegetation density (according to the MOD44B) above the threshold of $20 \%{ }^{12}$ We estimate biomass density for the same areas. ${ }^{13}$ The regression tree algorithm allows us to estimate biomass per unit area for Malawi in all $463.3 \mathrm{~m}$ x 463.3 m pixels.

Our estimates of biomass or forest area estimates are not directly comparable with the estimates provided in the Government of Malawi 1993 report and cannot be used to assess land cover change between 1990 and 2004. This is because we used different definitions for forested land and the remote sensing data have different spatial characteristics.

\section{Household Welfare and Biomass Use}

\footnotetext{
${ }^{11}$ We extracted MODIS observations taken at the beginning and end of the drying season. At the beginning of the drying season most vegetation still have leaves on, while at the end of the dry season only evergreen trees have leaves on them. This information is useful in separating evergreen vegetation from deciduous vegetation.

${ }^{12}$ We do not attempt to classify the landscape in land-cover type or forest classes as done in the 1993 report (e.g., Evergreen forests, Brachystegia, Grass, etc.). This is because our interest is mainly in estimating the volume of biomass per unit of land area, and land-cover type provides only limited information about biomass.

${ }^{13}$ Setting the tree density threshold to $20 \%$, may result in a value of zero biomass for regions characterized by a mixture of agriculture and trees.
} 
Biomass scarcity may be less problematic in slightly richer countries or in countries where there are substitutes available, but in Malawi, the almost singular dependence on forests for energy implies that scarcity can have an impact on household welfare, particularly for poor households. Households faced with scarcity may reduce their consumption of energy, walk longer distances to collect fuelwood or use lower quality fuelwood (Brouwer et al. 1997). Lower biomass also implies that there are fewer wild foods and products to be had and there may be indirect effects from changes in eco-system functions. We hypothesize that all of these factors can affect household well-being either by affecting household consumption directly, affecting income (from any limited sales of fuelwood and labor re-allocation) or through its impact on household health or leisure.

To test the link between household welfare and biomass, we estimate a reduced form equation with log of real annual per capita consumption expenditure as the measure of household welfare on the left hand side. Consumption expenditure covers a variety of food and non-food expenditures, including estimated expenditures on some products obtained from forests such as charcoal, poles, grasses, wild foods and meat. It does not include estimated expenditures on collected fuelwood. Thus, any effect of biomass on consumption is an overall 'net' effect that captures behavioral changes undertaken as a result of scarcity in fuelwood and other forest products.

We build our model of consumption expenditure based on an understanding of economic theory. Thus, our exogenous variables are those that are identified by economic theory and we test to see if there is a causal relationship between these variables and poverty. Our model relies strongly on a previous effort to estimate the determinants of poverty in Malawi using 1997-98 household data (National Economic Council, National Statistical Office, Government of Malawi and International Food Policy Research Institute 2001). This model is also documented in Mukherjee and Benson (2003). This model is also similar to the model used in Chapter 2 of this volume to assess determinants of poverty. Our main extension is in the use of biomass as a determinant of welfare.

In our reduced form model, the variable of interest on the right hand side is amount of biomass per hectare in the community. We postulate that household welfare and biomass stock have a nonlinear relationship. As biomass increases, welfare does not linearly increase but increases at a 
decreasing rate. We include biomass and biomass squared in the right hand side of the household welfare equation:

$$
\ln C_{j}=\gamma_{1}+\gamma_{2} B_{j}+\gamma_{3} B_{j}^{2}+\gamma_{4} M_{j}+\gamma_{5} H_{j}+\eta_{j}
$$

where $C_{j}$ is consumption expenditure of household $j . B_{j}$ and $B_{j}{ }^{2}$ are respectively biomass and biomass squared at the community level. $M_{j}$ is a vector of other community variables and $H_{j}$ is a vector of household characteristics described below. The $\eta_{j}$ is a random error term. The variables used in the estimation are listed in Table 2.

The land holdings of a household were classified into four categories: rain-fed, dimba, uncultivated and trees. Since rain-fed and dimba are the land used for cultivation in the previous wet and dry season respectively, we expect areas under these to positively affect household welfare. We found no relationship between the amount of uncultivated and tree land and consumption expenditure and dropped these variables from the analysis. Thus, area of land used by the household for rain-fed cultivation in the last rainy season, area of land used by the household for dimba cultivation in the last dry season, measures land assets of the household.

We estimate equation (1) for all households in the sample. We then estimate the same equation for households in the three regions: North, Central and South. We anticipate that the impact of biomass may be different for rich versus poor households. Thus, our final estimation of this equation uses the poverty line to divide the data into rich and poor categories.

\section{Labor Allocation}

The second question that interests us is whether biomass scarcity affects fuelwood collection and whether it reduces production-oriented activity. Thus, in our study we model two personal labor allocation decisions made by active men and women of age 10 and above: fuelwood collection and time spent on household agricultural production.

There is a small set of literature that looks at the effect of scarcity on time allocation. An early study in this area by Kumar and Hotchkiss (1988) examined the impact of deforestation on women's labor allocation. Their work on Nepal suggested that women increase their time spent on fuelwood collection when wood becomes scarce and this affects agricultural output. More 
recent papers by Cooke (1998a, 1998b) on Nepal show that scarcity motivates increased time on collection but has no significant effect on labor in agriculture. Adding to this thin literature is a paper by Fisher et al. (2005) using data from southern Malawi, which supports some of Cooke’s findings.

Cooke (1998a,b) and Fisher et al.(2005), while their empirical models differ, derive their labor allocation models from a neo-classical household production function framework. Similar models are used in Illahi and Grimard (2000) and Khandker (1988) who study labor allocation in different contexts in Pakistan and Bangladesh. We do not develop a formal model of household behavior for this paper; however, our partial equilibrium personal labor allocation model is rooted in the same household production and utility function framework.

The idea here is that of a rural representative household that functions in a subsistence setting and produces the goods that it consumes. Households choose the optimal levels of consumption goods and leisure. Some home produced goods (for example maize) may be generated with the use of market inputs, labor and land. Others, such as fuelwood are generated by the use of biomass and labor. Household behavior and utility is conditioned on several fixed household characteristics such as household size, health stock and education and so on. Households maximize utility by allocating optimal amounts of labor to different home production tasks and by purchasing market inputs subject to a full income constraint. At the margin, households equate the marginal value product of leisure to the net returns to labor in different tasks. This yields a set of labor supply equations that can be empirically estimated. Men and women's labor supply is a function of output prices, wages, and household and community characteristics that may affect productivity. Scarcity of biomass is expected to impact labor supply decisions.

Following Illahi and Grimard (2000) we model labor allocation as an individual decision influenced by household characteristics. This level of disaggregation allows us to control for individual characteristics and their relationship with the rest of the household in the labor allocation decision. For example, we can control for age, sex, health, and marital status of the individual. $^{14}$

\footnotetext{
${ }^{14}$ Alternate models (Cooke 1998a,b, for example) estimate labor demand and supply based on average household behavior versus individual allocative decisions. In these models, the wage rate is for an 'average' male or female member of the household. However, wages differ based on individual age, sex, education, and experience rather than because of household characteristics. This is the reason why we
} 
The model described below is estimated separately for men and women above 10. However, in Malawi most of the fuelwood collection is done by women. Thus, we describe of the model in terms of a representative woman.

In estimating labor supply equations, an empirical problem that needs to be accounted for is the presence of active men and women who do not participate in agriculture or fuelwood collection tasks. The determinants of the decision to collect fuelwood may be different from those of the decision to allocate hours to fuelwood collection. Whether a woman collects fuelwood may be a function of availability of substitutes and whether or not the household purchases fuelwood, which in turn may be influenced by household wealth. To address this, we model the personal labor allocation decisions in two stages. In the first stage an active woman decides whether or not to participate in the specific activity such as fuelwood collection or agricultural production. Those who decide to participate then decide how much time to spend on the respective activities.

The participation decision for activity $k=$ fuelwood collection, agricultural production may be represented by:

$$
\operatorname{Pr}\left(S_{i j k}=1\right)=\varphi\left(\delta_{1}+\delta_{1} B_{j}+\delta_{3} M_{j}+\delta_{4} H_{j}+\delta_{5} N_{i j}+e_{i j k}\right)
$$

The time spent on activity $k$ may be represented by:

$$
R_{i j k}=d_{1}+d_{2} B_{j}+d_{3} M_{j}+d_{4} H_{i j}+d_{5} N_{i j}+\varepsilon_{i j k}
$$

where $S_{i j k}$ is an indicator of participation that takes the value 1 if the $i$ th member of the $j$ th household participates in the $k$ th activity, fuelwood collection or agricultural production. $N_{i j}$ is a vector of individual member characteristics for the $i$ th member of the $j$ th household including age, marital status, number of children, and chronic illness, and $e_{i j k}$ is a random error term. $R_{i j k}$ is the number of hours spent on $k$ th activity by the $i$ th member of the $j$ th household and $\varepsilon_{i j k}$ is a random error term.

choose to estimate individual male and female labor supply functions versus a household labor supply function. 
The Real Value of Household Assets measures real value of household assets and is a proxy for wealth of the household. ${ }^{15}$ Since the active woman is likely to work in the rain-fed plots in the wet season and in the dimba plots in the dry season, the season dummies are interacted with the respective size of rain-fed and dimba plots. Bigger the size of uncultivated land in the household, it is likely the active woman will have more time and thus is more likely to participate in fuelwood collection. Similarly we expect larger size of the area with trees will make the active women in the household more likely to collect fuelwood.

It is important to provide some additional discussion about the biomass variable. Many of the papers (Kumar and Hotchkiss, 1988, Cooke 1998a,b) that have thus far studied the effects of natural resource scarcity on labor allocation do not have an exogenous measure of scarcity. Cooke estimates the shadow wage rate and uses this in her model as a measure of scarcity. Our paper because of its unique data set is able to directly assess the impact of biomass scarcity on labor allocation. Our hypothesis is that households will increase the time spent on fuelwood collection when faced with increased scarcity. They may consequently reduce time on agricultural productive activities. However, in modeling the effect of biomass on labor decisions we are influenced by information on some specific ways in which Malawian households react to scarcity. Brouwer et al. (1997) suggest that households when faced with great scarcity increase their time in collection up to a point, but after that they switch to alternate and lower quality sources of fuel wood. Thus, the labor supply function switches at a certain level of biomass scarcity. We model this by estimating two separate labor supply functions - one for biomass quantities lower than 20 cubic meters per hectare and one for higher quantities. We hypothesize that the active women who live in biomass scarce areas cope with the biomass scarcity in many different ways as compared with women who live where biomass is not scarce.

An important determinant of collection behavior is the opportunity cost of time. We expect that a higher opportunity cost would make woman less likely to collect fuelwood. We assume that the wage rate is a reasonable measure of the opportunity cost of time. However, not all women enter the formal labor market and do not report the wage rate. Therefore, in a fashion similar to Ilahi

\footnotetext{
${ }^{15}$ The Real Value of Household Assets is the total current value of household assets measured in constant MK. The assets considered are mortar/pestle, bed, table, chair, fan, air conditioner, radio, tape or CD player, television and VCR, sewing machine, kerosene stove, electric or gas stove, refrigerator, washing machine, bicycle, motorcycle, car, mini-bus, and lorry. These assets represent the wealth stock of the household. Most of these assets are for household use rather than used for productive activities (exception: mini-bus, lorry). We do not use a principal component based index of assets for these as the monetary value is available.
} 
and Grimard (2000), we follow Heckman's model to instrument the real average wage for women based on the wages and salaries reported by women and their socio-demographic characteristics. ${ }^{16}$ Our measure of opportunity cost of time is individually predicted wages, but does not account for the possible presence of different shadow wages for different activities (Cooke 1998a, Fisher et al. 2005).

We use Heckman's sample selection model (Heckman, 1978) to model the participation and labor allocation decisions of the active women in fuelwood collection. The choice of Heckman's model is influenced by the fact that some of the factors that affect both the participation decision as well as the hours spent on collecting fuelwood may have opposite effects on these two decisions. For example, easy access to fuelwood as measured by the size of household tree plot is expected to have positive effect on participation decision and negative effect on time allocation. The probability of participation is expected to be higher for women residing in households with larger woodlots. However, we expect women in these households to take less time in collecting fuelwood as compared with women who do not have access to personal wood lots. As a result, a Tobit model is not appropriate for fuelwood collection.

The hours spent on household agriculture is modeled as a Tobit equation. The use of Tobit model for the estimation of hours spent on household agriculture is based on the reasoning that the same variables that affect decision to take part in agricultural activities also affect the hours spent on agriculture. Unlike fuelwood collection, where some variables may have opposite effects on the participation and hours decision, for agricultural activities all the variables have similar effects. That is, the variables that are likely to increase the probability of participation in agriculture are also the variables that are likely to increase the hours spent on agriculture and vice versa. Thus, Tobit estimation method is appropriate for the time allocation to agricultural activities and not for fuelwood collection.

All but one right hand side variable are the same as that of hours spent on fuelwood collection. Productive Asset Index is an index of productive assets owned by the household. ${ }^{17}$ The sign of the

\footnotetext{
${ }^{16}$ The active woman's participation in the labor force is modeled as a function of whether or not she is married, number of children she has, the wage earned by the spouse, number of other active women in the household, the household size, and wet season dummies. The real wage of the active woman is modeled as a function of her age and education and respective squared terms, and wet season dummy. Both the models included regional intercept dummies to control for between region variation in the labor market.

${ }^{17}$ Productive Asset Index is an index of productive assets computed from the principal component analysis. The assets considered are: beer brewing drum, boat or canoe, fishing net, ox cart, wheel barrow, hand
} 
coefficient for the productive asset index is ambiguous. More productive assets may imply higher level of capital intensity and labor saving technology and thus fewer hours spent on agriculture. On the other hand, more assets may also point to more intense cultivation and thus more hours spent on agriculture. We estimate the agricultural activity labor allocation models separately for less and more biomass areas.

\section{RESULtS}

\section{Biomass and Forests in Malawi}

Figure 1 and Table 4 present a picture of biomass and forest cover in Malawi. ${ }^{18}$ The total amount of biomass in the country is 388 million cubic meters. The average biomass available is about 40 cubic meters per hectare; however, this number does not present an accurate picture because of the skewed distribution of biomass. As Figure 1 indicates, Malawi's forests are mainly in the Northern areas.

The northern region with159 million cubic meters of biomass has $41 \%$ of the country's biomass. The central region has 38 cubic meters per hectare and $38 \%$ of the biomass. The southern region is the area with the least amount of biomass (24\%).

It should be noted that these estimates are different than reported in the Biomass Assessment for 1990 (Government of Malawi 1993). A preliminary comparison of these two studies would suggest that biomass in Malawi has decreased by about 16\% between 1990 and 2004.

Specifically, the northern region went from 218 million cubic meters to 159 million cubic meters (27\% decline), the central region from 142 to 137 million cubic meters, a decrease of $14 \%$ and, the southern region from 102 to 92 million cubic meters, a $10 \%$ decrease. In fact it should be clarified that a precise comparison between the two studies is not feasible because of definitional differences between our study and the 1993 report: the two studies are based on different data with different spatial resolution and different methodologies. ${ }^{19}$ Nonetheless, it seems safe to

sprayer, panga, hoe, axe, and sickle. These assets are mainly used for agricultural and other productive activities and is thus assumed to affect agricultural labor hours but not hours spent on fuelwood collection. ${ }^{18}$ Figure 1 shows a map of biomass at the spatial resolution of 463.3 meters.

${ }^{19}$ The main reason for the difference between the 1993 report and our results is because of different definitions of forested land. In the 1993 report a large amount of land is classified as agriculture mixed with 
conclude that much of the degradation has occurred in the biomass rich north, with less occurring in the central and southern regions which had less forests in them.

Table 5 presents evidence of the dependence of households on biomass for energy based on the household data. As indicated in Table 5, 99\% of poor households use fuelwood as cooking fuel. Though the non-poor consume significantly more fuelwood as compared with the poor, proportionately more poor households collect fuelwood. A large majority of the households (55\%) collect fuelwood from unfarmed community areas. Less than $10 \%$ collect from their own lands. On average, a Malawian household spends the equivalent of MK 2558 per year per, per capita on fuelwood. ${ }^{20}$ That is, about 12 percent of total per capita annual consumption expenditure is spent on fuelwood.

The household heads were asked the time it takes for a one way walk to the location of fuelwood collection from their respective houses. We found no significant differences between the poor and non-poor households in terms of time taken for a one way walk to the location of fuelwood collection.

On average active women spent 1 hour and 30 minutes to collect fuelwood. The time spent in collection is slightly lower in the northern region but otherwise there is little difference in collection time between regions and rich and poor households. Eighty-four percent of all the active individuals who collected fuelwood were women.

Figure 3 combines household data with biomass estimates by overlaying district level biomass availability on district level poverty estimates. There is considerable variation in biomass at the district level. Furthermore, at the district level there is no one-to-one connection between poverty and biomass. While the south faces considerable biomass scarcity and poverty, even in the south there are districts that are much better off than others.

\section{Household Welfare and Biomass Use}

trees/forest; under our assumptions (namely the $20 \%$ threshold) some of this land area is classified as forest resulting in an increase of the forested area with respect to the 1993 estimates.

20 These numbers are self-reported. Since most Malawians collect and do not buy fuelwood, we expect that households used local prices to estimate the value of the fuelwood they use. 
Household welfare is expected to be influenced by biomass availability. We estimate the welfare-biomass relationship in equation (1) for the overall sample as well as for the sub samples of poor and non-poor and the North, Center and South regions. The summary relationship between consumption expenditure and biomass is presented in Table 6. The complete estimation results are in Appendix Table 2 and 3.

Table 6 indicates that the average effect of biomass on rural per capita consumption expenditure is significant but small. For example, a 10\% increase in biomass per hectare is associated with approximately $0.05 \%$ higher annual per capita consumption expenditure. These numbers are somewhat higher if only poor households are considered -- a 10\% increase in biomass per hectare is associated with a $0.1 \%$ higher annual per capital consumption expenditure. In the rural South, a $10 \%$ increase in biomass per hectare is associated with a $0.2 \%$ increase in welfare. Because these effects are small we conclude that households may be adjusting to biomass scarcity without suffering much welfare loss. The small loss of welfare is due to fuelwood as well as other uses of and benefits from biomass.

To put the impact of biomass on consumption in perspective, we compare it with the impact of rain-fed agricultural land. For example, a 10\% increase the size of the average rain-fed land holding by a poor household would result in a $0.4 \%$ increase in the per capita consumption expenditure. Thus, even though the effect of biomass scarcity on household welfare is small, it is not insignificant as compared with increases in agricultural land.

The quadratic relationship between biomass and consumption expenditure implies benefits from having access to more biomass increases at a decreasing rate. We find that the impact of biomass and its squared term are statistically significant for poor households, but they are not significant for non-poor households. This supports the hypothesis that the welfare of the poor is dependent on the stock of biomass as compared with that of the non-poor.

Figure 5 suggests that for an average rural household in Malawi consumption expenditure declines after biomass reaches 26 cubic meters per hectare in the community. ${ }^{21}$ Seventy-two percent of the rural households are in areas with biomass less than 26 cubic meters per hectare.

\footnotetext{
21 At the community level, the average biomass per hectare is 20 cubic meters per hectare. This number differs from the country average of 40 cubic meters per hectare because of differences in averaging weights.
} 
However, as indicated in Figure 6, a rural poor household continues to benefit from biomass stock till 39 cubic meters per hectare. Eighty percent of the rural poor households are in areas with biomass less than 39 cubic meters per hectare. Thus, most of the rural poor would benefit if average biomass per hectare almost doubles from 20 to 39 cubic meters.

Figure 6 shows the total welfare loss for the rural poor in various districts resulting from a decline of biomass per hectare. ${ }^{22}$ The vertical axis shows the loss in total annual welfare incurred by all poor rural households in the district resulting from a 1 cubic meter decline in biomass per hectare. The horizontal axis shows the average biomass concentration in each district. This figure identifies the combination of districts from the South and Center regions where the poor are most likely to gain from investments in biomass. These are the districts with large concentration of rural poor and low concentration of biomass. All the districts in the figure 6 would suffer an annual welfare loss as a result of increase in scarcity of biomass. The five districts that would incur a welfare loss of 4 million Malawi Kwacha or more per year are Lilongwe, Zomba, Dedza, Mangochi, and Kasungu. The overall welfare loss by all the poor for rural Malawi is 44.8 million Malawi Kwachas per year.

Some caveats apply to the above findings. Our measure of biomass may not adequately capture mixed and low density biomass such as sparse bush or bush mixed with agricultural land. It is likely that households shift to lower quality biomass for their fuelwood needs when they face extreme scarcity. A more refined measure of biomass may help explain the biomass-welfare relationship better. We also note that our measure of household welfare does not account for other benefits such as biodiversity conservation that may not translate directly to higher annual household consumption.

\section{Coping Strategies and Labor Allocation}

The estimates of fuelwood collection equations (2) and (3) for active women in overall rural Malawi, less biomass, and more biomass areas are shown in Table 7. Columns 1 and 2 show estimates for the overall rural Malawi. Columns 3 and 4 show estimates for the biomass scarce

\footnotetext{
${ }^{22}$ Three districts in the North region, Chitipa, Nikhata Bay, and Rumphi were excluded from Figure 6 because biomass concentrations in these districts are greater than the threshold level for the poor to benefit from an increase in biomass.
} 
areas where biomass stock is less than 20 cubic meters per hectare and columns 5 and 6 present results for areas with more biomass.

For overall rural Malawi, higher levels of biomass appear to make an active woman more likely to participate in fuelwood collection but does not affect hours spent on fuelwood collection. Some of the factors such as Dry Season Dimba Area Interaction that are significant for the overall rural Malawi estimation of the active women's fuelwood collection estimation are only significant for more biomass areas (Columns 1 and 5). Other factors such as Number of Children below five appear to affect overall rural Malawi, and less biomass areas estimations (Columns 1 and 3). Thus, we concentrate on the separate estimates for less biomass and more biomass areas rather than overall rural Malawi.

For both the biomass scarce and sufficient areas, higher stock of biomass increases the likelihood of collection and decreases the hours spent on fuelwood collection. In both cases, factors such as age of the active woman, uncultivated land held by the household and the marriage dummy appear to make an active woman more likely to participate in fuelwood collection. Age squared, wage rate, and substitute for collected fuelwood appear to make an active woman less likely to participate in fuelwood collection in both cases. Our interest is mainly in the number of hours spent in collection of fuelwood. We find that biomass scarcity has a significant but small effect on hours spent in collecting fuelwood. A one cubic meter decrease in biomass per hectare results, on average, in a one minute increase in the time spent by women on collection.

An important question is why there is such a small change in time spent in the face of increasing scarcity. One explanation is that women undertake multiple tasks when they collect fuelwood, which may also be why hours spent in fuelwood do not differ much between the biomass rich north and the biomass poor south. Households also use multiple strategies to cope with biomass scarcity and do not just change their labor allocation behaviors. These conclusions are supported by micro-studies such as that by Brouwer et al. (1997), who indicate that women in Ntechu District in central Malawi combine fuelwood collection with field work or change the frequency of collection in response to scarcity. Another explanation for the low variance in labor time in our study may lie in the nature of the data collected, since the labor allocation responses were rounded to half hour segments. 
Table 8 shows the results from our estimation of female agriculture labor supply in overall rural Malawi, less and more biomass areas. Though for overall rural Malawi higher biomass appear to decrease hours spent by active women in agricultural productions, variation in biomass stock within less and more biomass areas does not appear to affect hours spent by an active woman in household agriculture. Other significant factors have the expected signs. For example, larger household size implies larger supply of labor in the household and thus lesser number of hours for the active woman in the agricultural fields. Larger size of cultivated land in dry and in wet season implies more hours whereas larger size of uncultivated fallow implies shorter hours. Higher wages means higher opportunity costs for the active woman and thus shorter hours in the fields.

We find strong evidence of negative impact of chronic illnesses in the family on the number of hours spent in agriculture by an active woman. However, we do not find such a strong effect on either the participation or the number of hours an active woman spends on fuelwood collection. Similarly recent personal illness appears to have a negative effect on the number of hours in agriculture but has no effect on the hours spent on fuelwood collection. This is likely to be because agricultural labor is more strenuous than labor required for fuelwood collection.

Relatively small numbers of men collect fuelwood. Men do not report collecting any fuelwood in 94 percent of the households surveyed. We find no evidence of biomass stock affecting fuelwood collection decision and hours spent collecting fuelwood by active men. We report the estimation results for men's labor allocation in fuelwood collection and agricultural activities in Appendix Tables 2 and 3. Interestingly while married women are more likely to collect fuelwood, married men are less likely. Larger household size also makes men less likely to collect fuelwood. This effect is not always significant for women.

Biomass shows perverse sign for hours spent on agricultural production by men. That is, higher biomass stock results in less number of hours by men in agricultural production in the more biomass areas and in overall estimates. We also find similar results for women in the overall estimates but they are not significant for more and less biomass areas. We speculate that men (and women) may spend time collecting other forest products instead of agricultural production where biomass is not scarce. 


\section{DISCUSSION AND CONCLUSIONS}

Malawi is a country in biomass distress. It is also one of the poorest countries in Africa. Our goal in this paper is to understand how biomass access varies across the country, how this varied access affects the poor and how the poor cope with scarcity.

Remote sensing data shows that a large proportion of the biomass available in Malawi is in the northern region, an area that is much less populated than the rest of the country. The South with much less biomass faces considerable scarcity. Overlaying biomass and poverty maps on each other shows that at the district level there is no one-to-one relationship between poverty and forest degradation.

Ninety-seven percent of rural Malawians depend on fuelwood as their primary source of energy for cooking. Almost eighty percent of households collect fuelwood directly from areas close by. Ninety percent of the poor collect their own fuelwood. On an average day when women go out to collect fuelwood, they spend one and half hours on this task. Thus, biomass scarcity matters for the welfare of rural Malawians.

Our analyses suggest that biomass scarcity is associated with small but significantly lower household welfare, particularly for the rural poor. At current high levels of scarcity, 80 percent of the rural poor households are likely to benefit moderately from an increase in biomass in the community. The districts that are likely to gain the most from investments in biomass are Lilongwe, Zomba, Dedza, Kasungu, and Mangochi.

There have been attempts in the past to invest in fuelwood in Malawi and to induce rural households to plant more trees. Unfortunately, these efforts have largely been unsuccessful (French 1986, Dewees 1995, Walker 2004,). Our results may provide an economic explanation for the households' decision not to plant more trees despite various policy interventions. The net returns to households from participating in biomass related projects may not be adequate. This does not mean that Malawians do not perceive biomass to be scarce. Rather, it indicates that given various constraints, households may choose to not use scarce land and labor to plant fuelwood oriented tree crops. This suggests that understanding household responses to scarcity has to be integral to any strategy to resolve Malawi's deforestation problems. 
In this paper, we examine whether households increase their time in fuelwood collection in response to fuelwood scarcity and whether this has an impact on agricultural labor. Our analysis indicates that rural women do cope with biomass scarcity by increasing the time they spend on collection. However, this increase is small suggesting that households use multiple strategies to cope with scarcity. On a positive note, biomass scarcity does not have negative affect agricultural activity undertaken by women or men. Of more concern in this regard is the effect of chronic illness within the family.

While poverty and environment are inter-linked in Malawi, physical scarcity of biomass may not always translate to economic scarcity of fuelwood. When faced with biomass scarcity, the rural poor may cope by collecting lower quality biomass and undertaking simultaneous tasks with fuelwood collection. A better understanding of these strategies may help policy-makers target poverty eradication and biomass conservation more effectively in rural Malawi. 


\section{REFERENCES}

Adhikari, B. 2003. "Property Rights and Natural Resources: Socio-Economic Heterogeneity and Distributional Implications of Common Property Resource Management.” Working Paper 1-03. South Asian Network for Development and Environment Economics (SANDEE): Katmandu, Nepal.

Baccini, A, M.A. Friedl, C.E. Woodcock and R. Warbington (2004). Forest biomass estimation over regional scales using multisource data. Geophysical Research Letters, 31(L10501).

Bluffstone, R.A. 1995. The effect of labor market performance on deforestation in developing countries under open access: An example from rural Nepal. Journal of Environment and Development Economics, 4; (2): 161-76.

Brouwer, I.D., J.C.Hoorweg and M.J. Van Liere. 1997. When households run out of fuel: Responses of rural households to decreasing fuelwood availability, Ntcheu District, Malawi. World Development, Vol 25, No. 2: 255-266.

Breiman, L., Friedman, J. H., Olshen, R. A., and Stone, C. J. 1984. Classification and Regression Trees. Wadsworth, Belmont, CA.

Cavendish, W. 2000. Empirical regularities in the poverty-environment relationship of rural households: evidence from Zimbabwe. World Development (U.K.); 28, No. 11:1979-2003, November 2000.

Cooke, P. A. 1998a. Intra-household labor allocation responses to environmental good scarcity: a case study from the hills of Nepal. Economic Development and Cultural Change vol 46, no. 4: 807-830.

Cooke, P. A. 1998b. The effect of environmental good scarcity on own-farm labor allocation: the case of agricultural households in rural Nepal. Environment and Development Economics, No. 3: 443-469. 
Cohen, W. B. and Spies, T. A. 1992. Estimating structural attributes of Douglas-Fir/Western Hemlock forest stands from Landsat and Spot imagery. Remote Sensing of Environment, Volume 41, 1-17.

Dasgupta, P. 1995. Population, poverty and the local environment. Scientific American, vol 272, no. 2: 26-31.

Dasgupta, S. U. Deichmann, C. Meisner, and D. Wheeler. 2005. Where is the povertyenvironment nexus? Evidence from Cambodia, Lao, PDR and Vietnam. World Development, vol 33, No. 4: 617-638.

Dewees, P. 1989. The woodfuel crisis re-considered: Observations on the dynamics of abundance and scarcity. World Development, vol 17, no. 8: 1159-1172.

Dewees, P. 1995. Trees on farms in Malawi: Private investment, public policy and farmer choice. World Development, vol 23, no, 7: 1085-1102.

Ekbom, A. \& J. Bojö 1999. Poverty and Environment: Evidence of Links and Integration in the Country Assistance Strategy Process. World Bank Africa Region Discussion Paper No. 4. Washington, DC: World Bank.

Duraiappah, A. 1998. Poverty and environmental degradation: A review and analyses of the nexus. World Development, vol 26, No. 12: 2169-2179.

Ezzati, M and D. M. Kammen. 2001. Indoor air pollution from biomass combustion and acute respiratory infections in Kenya: an exposure-response study. The Lancet, vol 358, 619-24.

Fisher, M. 2004. Household welfare and forest dependence in southern Malawi. Environment and Development Economics 9: 135-154.

French, D. 1986. Confronting an Unsolvable Problem: Deforestation in Malawi. World Development, vol 14, no. 4: 531-540. 
Fisher, M and G. Shively. 2005. Can income programs reduce tropical forest pressure? Income shocks and forest use in Malawi. World Development, vol 33, No. 7: 1115-1128/

Fisher, M, G. Shively, and S. Buccola. 2005. Activity Choice, Labor Allocation and Forest Use in Malawi. Land Economics, vol 81, no. 4: 503-517.

Food and Agriculture Organization (FAO 2005). Forestry 2005 Country Tables, Malawi. www.fao.org/forestry/site/32085/en

Franklin, J. 1986. Thematic mapper analysis of coniferous forest structure and composition. International Journal of Remote Sensing, Volume 7, 1287-1301

Friedl, M. A. and Brodley, C. E. 1997. Decision Tree classification of land cover from remotely sensed data. Remote Sensing of Environment, Volume 61, 399-409

Government of Malawi, Ministry of Forestry and Natural Resources, Department of Forestry, 1993, Forest Resources Mapping and Biomass Assessment for Malawi. Lilongwe, Malawi.

Heckman, J.J. 1978. Sample selection bias as a specification error. Econometrica, Volume 47, 153-161.

Ilahi, N and F. Grimard (2000). Public infrastructure and private costs: Water supply and time allocation of Women in rural Pakistan. Economic Development and Cultural Change, 49 (1): 4575.

IFPRI, 2000. Poverty Monitoring Service Policy Brief No. 2. Malawi State of the Environment Report 1998

Jodha, N. 1986. Common property resources and rural poor in dry regions of India. Economic Political Weekly, vol 21, No. 27.

Khandker, S. R. 1988. Determinants of women’s time allocation in rural Bangladesh. Economic Development and Cultural Change, 37 (1): 111-126. 
Malawi Sustainable Development Network Programme (SDNP), 1998. State of the Environment Report. http://www.sdnp.org.mw

Michaelsen, J., David, S. S., Friedl, M. A, Davis, F. W. and Dubayah, R. C. 1994. Regression Tree analysis of satellite and terrain data to guide vegetation sampling and survey. Journal of Vegetation Science, Volume 5, 673-686.

Minde, I.J., G. Kowero, D. Ngugi and J. Luhanga. 2001.Agricultural Land Expansion and Deforestation in Malawi. Forest, Tress and Livelihoods, vol 11: 167-182.

Mukherjee S. and T. Benson. 2003. The determinants of Poverty in Malawi, 1998. World Development vol 31, no. 2: 339-358

R. B. Myneni, J. Dong, C. J. Tucker, R. K. Kaufmann, P. E. Kauppi, J. Liski, L. Zhou, V. Alexeyev, and M. K. Hughes. 2001. A large carbon sink in the woody biomass of Northern forest. Proceedings of the National Academy of Sciences, Volume 98, 14784-14789.

Nankuni. F. 2004. Environmental degradation, resource scarcity and children's welfare in Malawi : School attendance, school progress and children's health. A Ph.D. thesis in agricultural economics and demography. Pennsylvania State University, the Graduate School, College of Agricultural Sciences.

National Economic Council, National Statistical Office, and IFPRI, 2001, The determinants of Poverty in Malawi: An analysis of the Malawi Integrated Household Survey 1997-97

Nerlove, M. 1991. Population and the environment: A parable of firewood and other tales. American Journal of Agricultural Economcs. Vol 73: 1334-47.

Puhr, C. B. and Donoghue, D. N. M. 2000. Remote sensing of upland conifer plantations using Landsat TM data: A case study from Galloway, South-West Scotland. International Journal of Remote Sensing, Volume 21, 633-646.

Shugart, H. H., Chavez, L. B. and Kasischke, E. S., 2000. Determination of stand properties in boreal and temperate forests using high-resolution imagery. Forest Science, Volume 46, 478-486. 
Walker, P. A. 2004. Roots of crisis: Historical narratives of tree planting in Malawi. Historical Geography, vol 32: 89-109.

World Resources Institute (WRI) 2003. Earth Trends Table, Forests, Grasslands and Drylands. http://earthtrends.wri.org/pdf_library/data_tables/for1_2003.pdf 
Figure 1: Biomass distribution at the year 2004 derived from remotely sensed data recorded by MODIS sensor

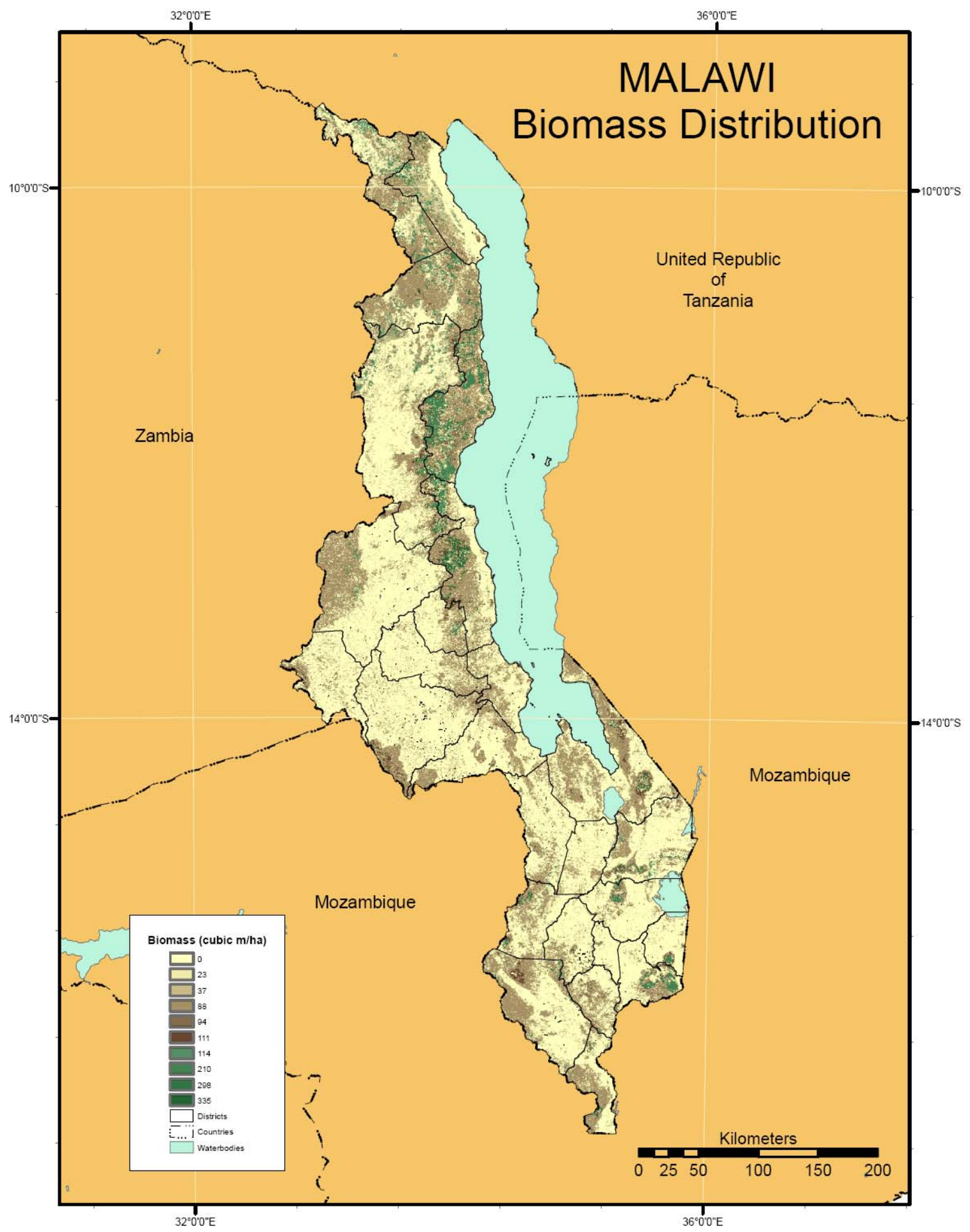


Figure 2: Map of 492 enumeration areas

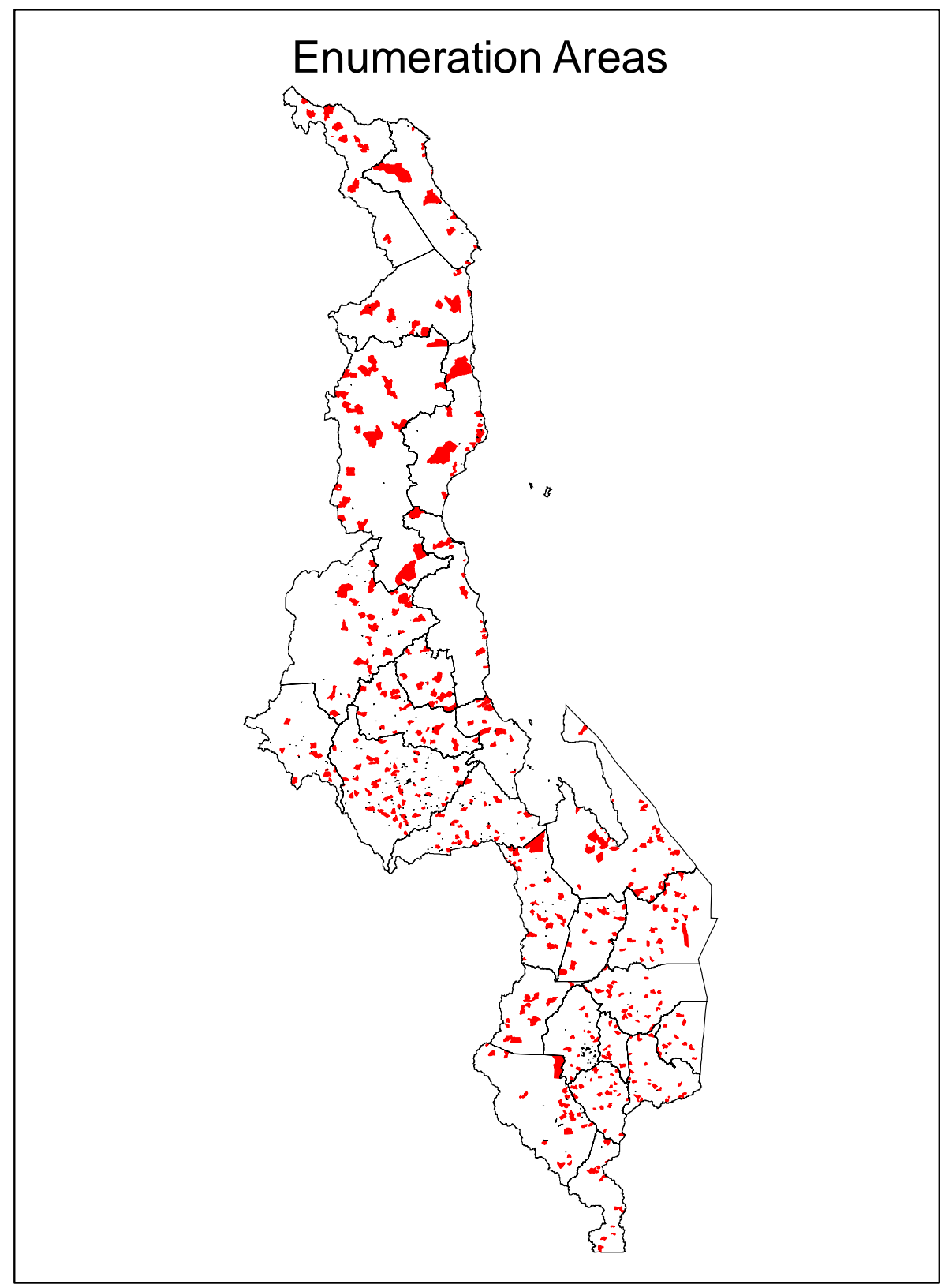


Figure 3: Average district biomass at the year 2004 intersected with poverty rates at the district level

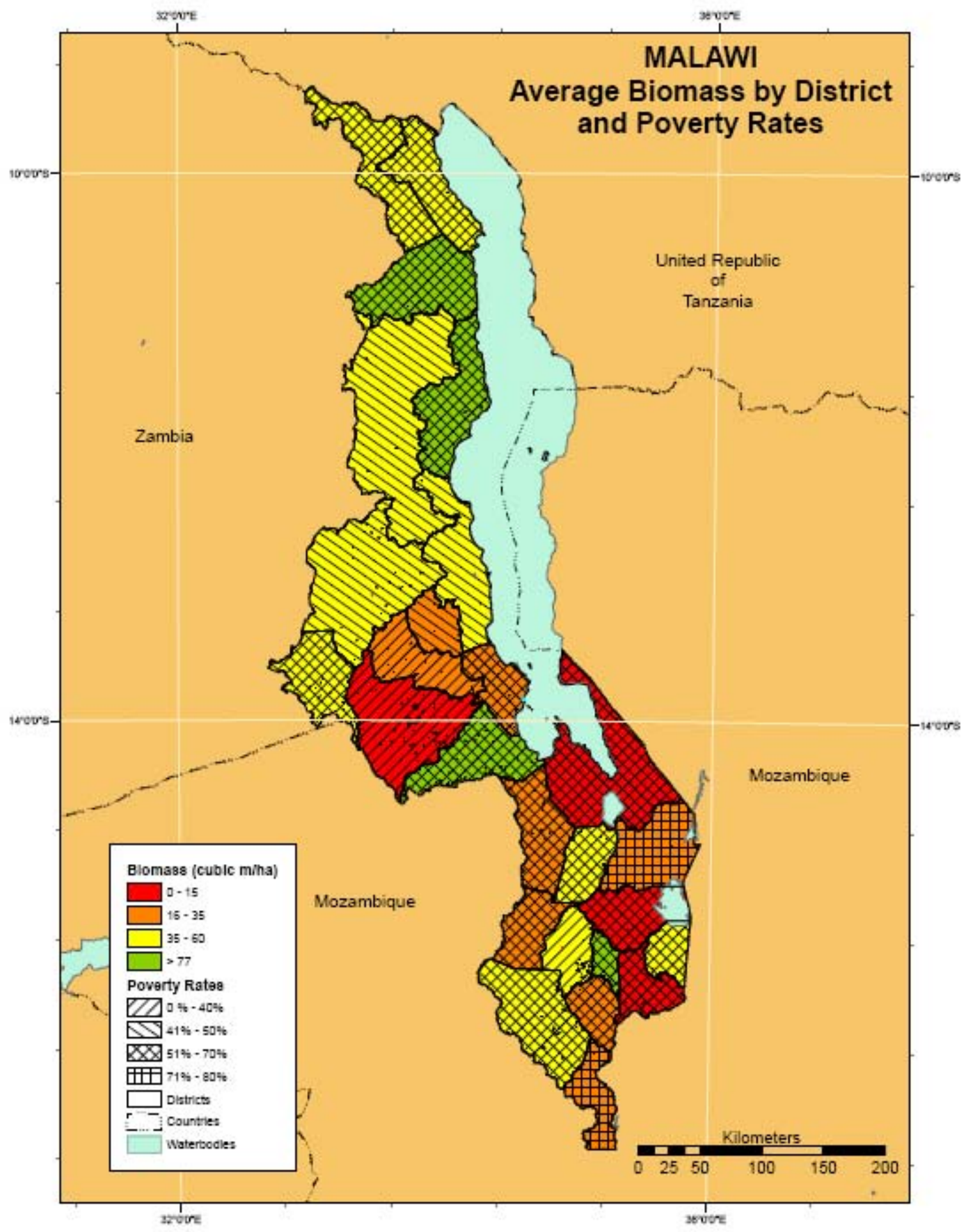


Figure 4: Overall quadratic relationship between biomass and household consumption

\section{Change in Welfare for All Rural}

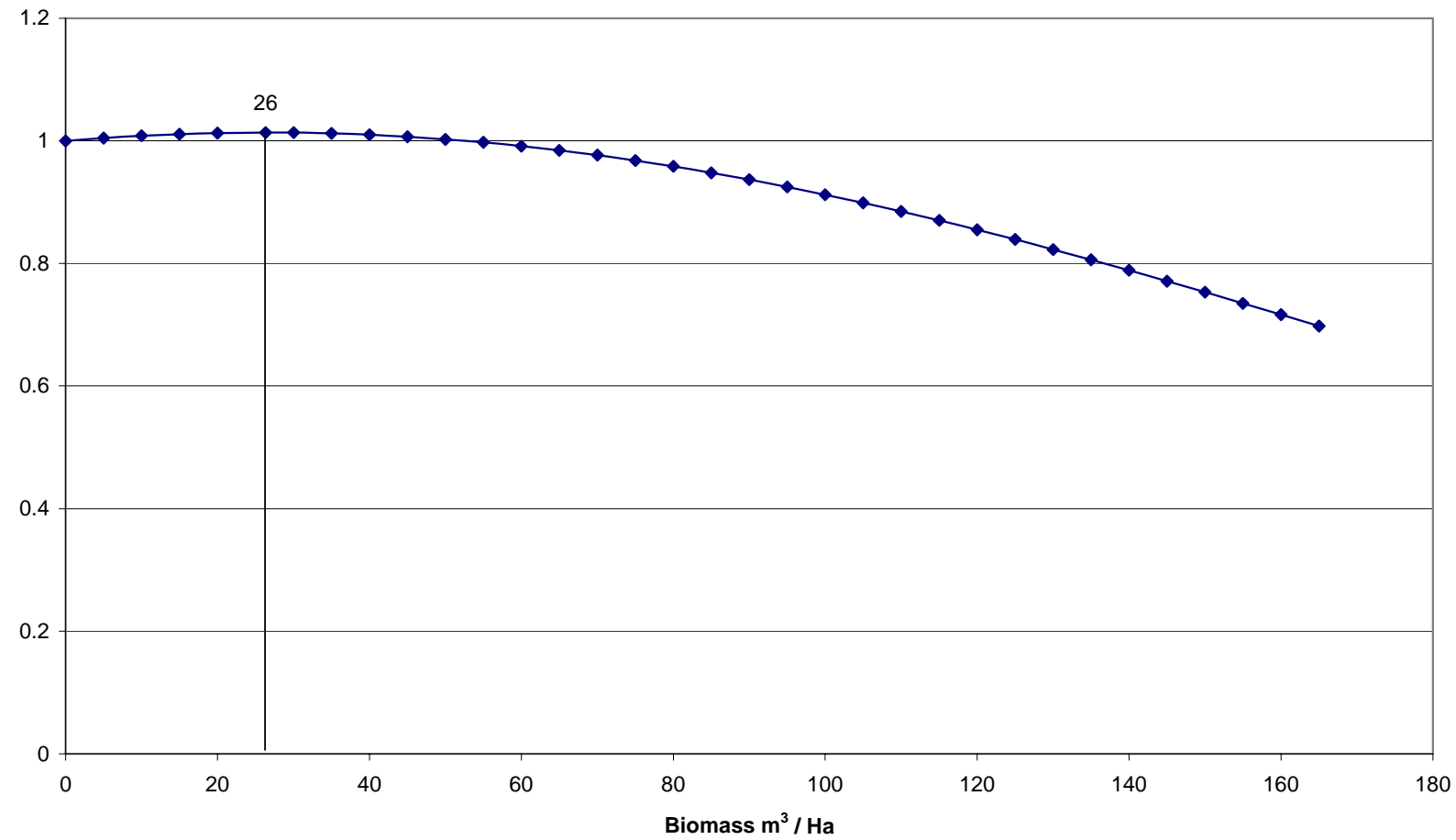


Figure 5: Quadratic relationship between biomass and household consumption for the poor

\section{Change in Welfare for Poor Rural}

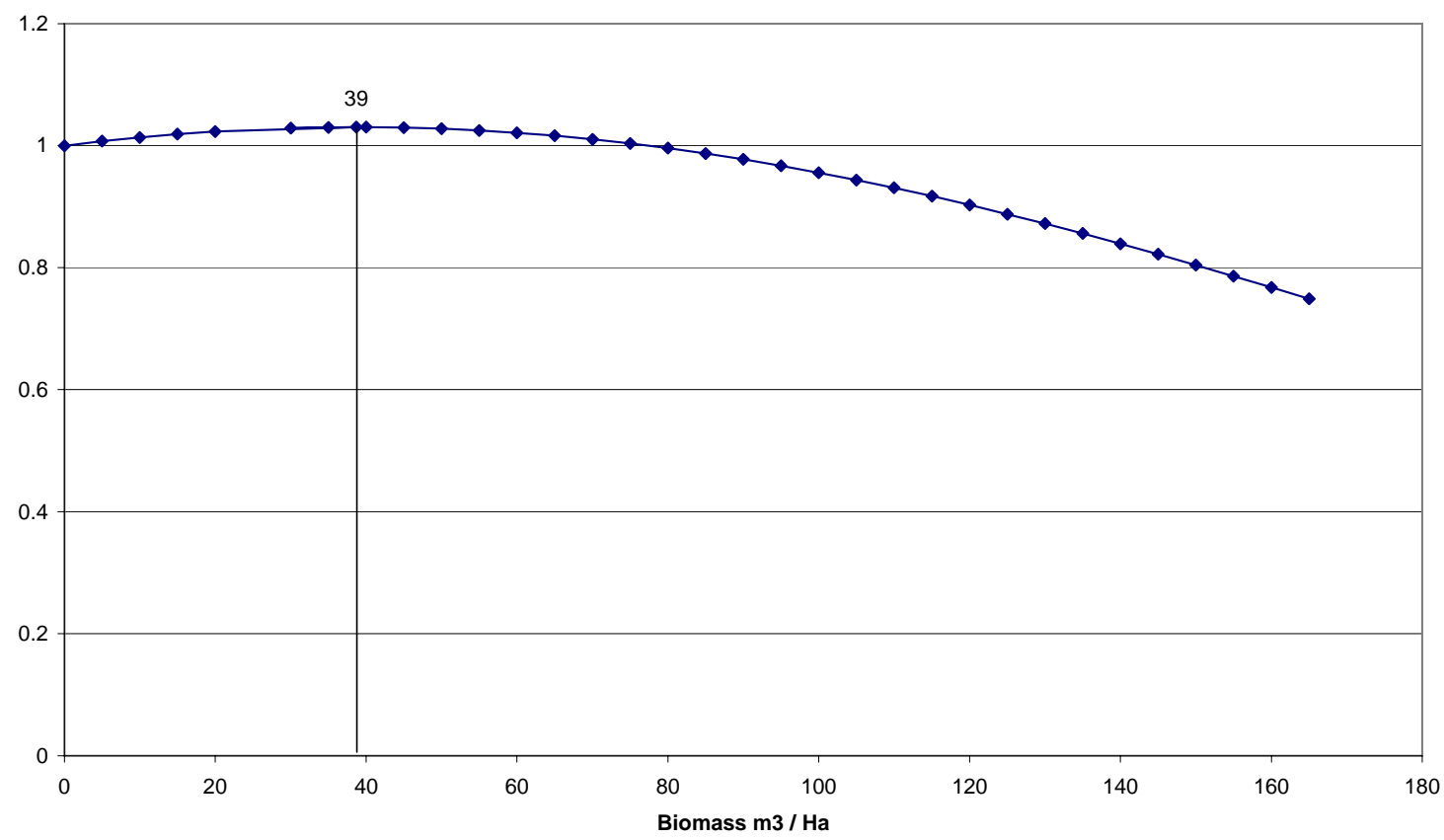


Figure 6: Annual welfare loss for the rural poor from 1 percent decline in biomass in the districts

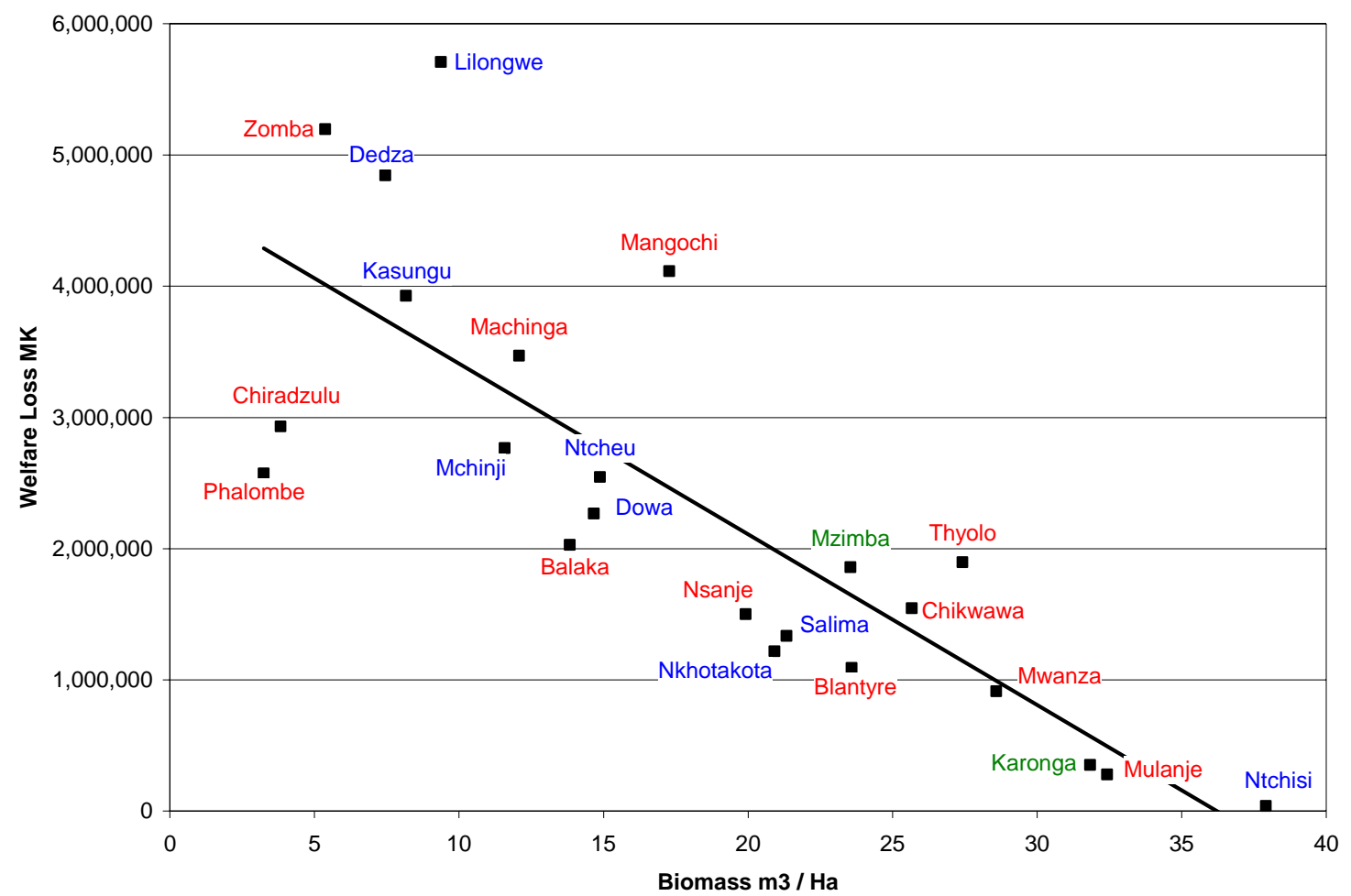

Note: The names of the districts from South are in red, those from Center are in blue and those from North are in green.

Three districts in the North region, Chitipa, Nikhata Bay, and Rumphi were excluded. Biomass concentrations in these districts are greater than the threshold level for the poor to benefit from an increase in biomass. 
Table 1: Community Level Indicators in the regions

\begin{tabular}{|l|r|r|r|r|}
\hline & \multicolumn{1}{l|l}{$\begin{array}{l}\text { Rural } \\
\text { North }\end{array}$} & $\begin{array}{l}\text { Rural } \\
\text { Centre }\end{array}$ & \multicolumn{1}{l|}{$\begin{array}{l}\text { Rural } \\
\text { South }\end{array}$} & \multicolumn{1}{l|}{ Total } \\
\hline Population Density & 0.18 & 0.14 & 0.25 & 0.20 \\
\hline Number of Agricultural Households in Community & 302.3 & 295.3 & 267.2 & 283.3 \\
\hline Distance to Asphalt Road KM & 38.9 & 16.8 & 16.5 & 19.8 \\
\hline Daily Market Distance KM & 12.5 & 9.5 & 5.3 & 8.0 \\
\hline Weekly Market Distance KM & 7.5 & 5.3 & 5.2 & 5.5 \\
\hline ADMARC Market Distance KM & 12.9 & 12.9 & 9.0 & 11.1 \\
\hline Distance to Nearest Market KM & 3.5 & 3.2 & 2.4 & 2.9 \\
\hline Post Office Distance KM & 12.5 & 10.1 & 9.3 & 10.1 \\
\hline Primary School Distance KM & 26.9 & 2.3 & 3.1 & 5.5 \\
\hline District Boma Distance KM & 55.9 & 39.2 & 38.5 & 41.4 \\
\hline Urban Center Distance KM & 170.5 & 106.9 & 94.2 & 110.4 \\
\hline Bank Distance KM & 62.3 & 29.2 & 23.0 & 31.3 \\
\hline Average Distances to Various Facilities KM & 46.3 & 27.2 & 23.4 & 28.3 \\
\hline
\end{tabular}


Table 2: Community and household variables in estimation of consumption

\begin{tabular}{|c|c|c|}
\hline & $(1)$ & $(2)$ \\
\hline Variables Description & Type & Unit \\
\hline \multicolumn{3}{|l|}{$\begin{array}{l}\text { Community Level } \\
\text { Variables: }\end{array}$} \\
\hline Biomass & $\mathrm{C}$ & $\mathrm{m} 3 / \mathrm{Ha}$ \\
\hline Biomass Squared & $\mathrm{C}$ & {$[\mathrm{m} 3 / \mathrm{Ha}]^{2}$} \\
\hline $\begin{array}{l}\text { Regular bus service in the } \\
\text { community }\end{array}$ & $\mathrm{D}$ & 0,1 \\
\hline Health clinic in community & $\mathrm{D}$ & 0,1 \\
\hline $\begin{array}{l}\text { EA is a Boma or a trading } \\
\text { center }\end{array}$ & $\mathrm{D}$ & 0,1 \\
\hline \multicolumn{3}{|l|}{$\begin{array}{l}\text { Travel time to the nearest } \\
\text { Boma: }\end{array}$} \\
\hline Less than 20 minutes & (Default) & \\
\hline 20 to 30 minutes & $\mathrm{D}$ & 0,1 \\
\hline 30 to 45 minutes & $\mathrm{D}$ & 0,1 \\
\hline 45 to 60 minutes & $\mathrm{D}$ & 0,1 \\
\hline More than 60 minutes & $\mathrm{D}$ & 0,1 \\
\hline $\begin{array}{l}\text { The ADMARK market in } \\
\text { the community }\end{array}$ & $\mathrm{D}$ & 0,1 \\
\hline Bank in the community & $\mathrm{D}$ & 0,1 \\
\hline $\begin{array}{l}\text { Daily market in the } \\
\text { community }\end{array}$ & $\mathrm{D}$ & 0,1 \\
\hline $\begin{array}{l}\text { Tarmac/asphalt road in } \\
\text { the community }\end{array}$ & $\mathrm{D}$ & 0,1 \\
\hline \multicolumn{3}{|l|}{$\begin{array}{l}\text { Household Level } \\
\text { Variables: }\end{array}$} \\
\hline $\begin{array}{l}\text { Female-headed } \\
\text { households }\end{array}$ & $\mathrm{D}$ & 0,1 \\
\hline $\begin{array}{l}\text { Head of the household is a } \\
\text { widow or a widower }\end{array}$ & $\mathrm{D}$ & 0,1 \\
\hline \multicolumn{3}{|l|}{$\begin{array}{l}\text { Age of the head of the } \\
\text { household }\end{array}$} \\
\hline Less than 26 & (Default) & \\
\hline 26 to 35 & $\mathrm{D}$ & 0,1 \\
\hline 36 to 45 & $\mathrm{D}$ & 0,1 \\
\hline 46 to 55 & $\mathrm{D}$ & 0,1 \\
\hline 56 to 65 & $\mathrm{D}$ & 0,1 \\
\hline 66 and above & $\mathrm{D}$ & 0,1 \\
\hline Household size & $\mathrm{C}$ & Number \\
\hline Household size squared & $\mathrm{C}$ & $\begin{array}{l}{\left[\text { Number }^{2}\right]} \\
/ 100\end{array}$ \\
\hline
\end{tabular}

\begin{tabular}{|c|c|c|}
\hline & $(1)$ & $(2)$ \\
\hline Variables Description & Type & Unit \\
\hline \multicolumn{3}{|l|}{$\begin{array}{l}\text { Number of children in the age } \\
\text { groups of }\end{array}$} \\
\hline $0-4$ & $\mathrm{C}$ & Number \\
\hline $5-10$ & $\mathrm{C}$ & Number \\
\hline $11-14$ & $\mathrm{C}$ & Number \\
\hline \multicolumn{3}{|l|}{$\begin{array}{l}\text { Highest level of education in } \\
\text { the household: }\end{array}$} \\
\hline No education & (Default) & \\
\hline Some primary & $\mathrm{D}$ & 0,1 \\
\hline Completed primary & $\mathrm{D}$ & 0,1 \\
\hline Post primary & $\mathrm{D}$ & 0,1 \\
\hline $\begin{array}{l}\text { The chronic illness in the } \\
\text { household }\end{array}$ & $\mathrm{D}$ & 0,1 \\
\hline \multicolumn{3}{|l|}{ Religion: } \\
\hline None/ Traditional & (Default) & \\
\hline Islam & $\mathrm{D}$ & 0,1 \\
\hline Catholic & $\mathrm{D}$ & 0,1 \\
\hline$C C A P$ & $\mathrm{D}$ & 0,1 \\
\hline Other Christian religion & $\mathrm{D}$ & 0,1 \\
\hline $\begin{array}{l}\text { Household has wage or salary } \\
\text { income }\end{array}$ & $\mathrm{D}$ & 0,1 \\
\hline $\begin{array}{l}\text { Household has non-farm } \\
\text { enterprise }\end{array}$ & $\mathrm{D}$ & 0,1 \\
\hline \multicolumn{3}{|l|}{$\begin{array}{l}\text { Eight Agricultural } \\
\text { Development Districts (ADD): }\end{array}$} \\
\hline Karonga & $\mathrm{D}$ & 0,1 \\
\hline Mzuzu & $\mathrm{D}$ & 0,1 \\
\hline Kasungu & $\mathrm{D}$ & 0,1 \\
\hline Salima & $\mathrm{D}$ & 0,1 \\
\hline Lilongwe & $\mathrm{D}$ & 0,1 \\
\hline Machinga & $\mathrm{D}$ & 0,1 \\
\hline Blanyre & $\mathrm{D}$ & 0,1 \\
\hline Ngabu & (Default) & \\
\hline \multicolumn{3}{|l|}{$\begin{array}{l}\text { The land holdings of a } \\
\text { household: }\end{array}$} \\
\hline $\begin{array}{l}\text { Area under rain-fed } \\
\text { Cultivation }\end{array}$ & $\mathrm{C}$ & На \\
\hline $\begin{array}{l}\text { Area under dimba } \\
\text { Cultivation }\end{array}$ & $\mathrm{C}$ & На \\
\hline Household cultivated tobacco & $\mathrm{D}$ & 0,1 \\
\hline
\end{tabular}

Type: C continuous variable. D: Indicator variable, takes value 1 if a condition is satisfied and 0 otherwise. 
Table 3: Community and household variables in estimation of labor allocation estimates

\begin{tabular}{|l|l|l|}
\hline Variable Description & Type & Unit \\
\hline Regional and other Variables: & & \\
\hline Centre Region & D & 0,1 \\
\hline South Region & D & 0,1 \\
\hline Wet Season & D & 0,1 \\
\hline Community Level Variables: & & \\
\hline Distance to ADMARC Market & C & Km \\
\hline Distance to Asphalt Road & C & Km \\
\hline Elevation & C & Meters \\
\hline Biomass & C & m3/Ha \\
\hline Price of Maize Grain & C & Malawian Kwacha / Kg \\
\hline Household Level Variables: & & \\
\hline Education for Head: Senior Primary or more & D & 0,1 \\
\hline Household Size & C & Number \\
\hline Real Value of Household Assets & C & '000 Malawian Kwacha \\
\hline Wet Season and Wet Area Interaction & C & Ha \\
\hline Dry Season and Dimba Area Interaction & C & Ha \\
\hline Uncultivated Area & C & Ha \\
\hline Area with Trees & C & Ha \\
\hline Number of Other Members Chronically Ill in Household & C & Number \\
\hline Substitute for collected fuelwood & D & 0,1 \\
\hline Productive Assets Index & C & Index \\
\hline Individual Level Variables: & & \\
\hline Age & C & Years \\
\hline Age Square & C & {$\left[\right.$ Years] ${ }^{2}$} \\
\hline Predicted Wage for Women & C & Malawian Kwacha / Day \\
\hline Number of Children Below Five & C & Number \\
\hline Married & D & 0,1 \\
\hline Illness or Injury in Past Two Weeks & D & 0,1 \\
\hline Suffer from a Chronic Illness & D & 0,1 \\
\hline Type: Contnuus & & Kariab. D: \\
\hline
\end{tabular}

Type: C continuous variable. D: Indicator variable, takes value 1 if a condition is satisfied and 0 otherwise. 
Table 4: Biomass Distribution

\begin{tabular}{|c|c|c|c|c|c|c|c|}
\hline DistrictID & $\begin{array}{l}\text { Area distr. } \\
\text { (1000 ha) }\end{array}$ & District name & $\begin{array}{l}\text { Fuel coll. } \\
\text { Hours/day }\end{array}$ & $\begin{array}{c}\text { Poverty } \\
\text { rates }\end{array}$ & $\begin{array}{c}\text { Biomass } \\
\text { Volume } 2004 \\
\text { (1000 cubic } \\
\text { meters) }\end{array}$ & $\begin{array}{l}\text { Biomass } \\
\text { Volume } \\
\text { (cubic } \\
\text { meters/ha) } \\
\end{array}$ & $\begin{array}{c}\text { Biomass } \\
\text { Volume } \\
1990(1000 \\
\text { cubic } \\
\text { meters) }\end{array}$ \\
\hline \multicolumn{8}{|l|}{ North } \\
\hline 101 & 425 & Chitipa & 1.22 & 0.67 & 25146 & 59.1 & 33126 \\
\hline 102 & 342 & Karonga & 1.12 & 0.55 & 17250 & 50.5 & 34788 \\
\hline 103 & 418 & Nkhata Bay & 1.25 & 0.63 & 33664 & 80.6 & 32658 \\
\hline 104 & 466 & Rumphi & 1.76 & 0.62 & 35747 & 76.7 & 35069 \\
\hline 105 & 1064 & $\begin{array}{l}\text { Mzimba/Mzuzu } \\
\text { City }\end{array}$ & 1.12 & 0.47 & 47196 & 44.3 & 81855 \\
\hline $\begin{array}{l}\text { Region } \\
\text { subtotal }\end{array}$ & 2715 & & & & 159004 & 58.6 & 217496 \\
\hline \multicolumn{8}{|l|}{ Central } \\
\hline 201 & 807 & Kasungu & 1.79 & 0.45 & 33264 & 41.2 & 34541 \\
\hline 202 & 433 & Nkhotakota & 2.26 & 0.48 & 23190 & 53.5 & 33260 \\
\hline 203 & 172 & Ntchisi & 0.78 & 0.47 & 6014 & 34.9 & 5999 \\
\hline 204 & 307 & Dowa & 1.66 & 0.37 & 6438 & 21.0 & 7867 \\
\hline 205 & 215 & Salima & 2.00 & 0.57 & 5289 & 24.6 & 7909 \\
\hline 206 & 623 & $\begin{array}{l}\text { Lilongwe/Lilongwe } \\
\text { City }\end{array}$ & 1.15 & 0.33 & 7186 & 11.5 & 20545 \\
\hline 207 & 315 & Mchinji & 1.41 & 0.60 & 12525 & 39.8 & 7495 \\
\hline 208 & 376 & Dedza & 1.25 & 0.55 & 32674 & 86.8 & 13417 \\
\hline 209 & 326 & Ntcheu & 1.78 & 0.52 & 10122 & 31.1 & 10716 \\
\hline $\begin{array}{l}\text { Region } \\
\text { subtotal }\end{array}$ & 3575 & & & & 136702 & 38.2 & 141749 \\
\hline \multicolumn{8}{|l|}{ South } \\
\hline 301 & 674 & Mangochi & 1.94 & 0.61 & 7277 & 10.8 & 32831 \\
\hline 302 & 394 & Machinga & 1.56 & 0.74 & 13465 & 34.2 & 13046 \\
\hline 303 & 312 & Zomba/Zomba City & 1.41 & 0.64 & 2936 & 9.4 & 3144 \\
\hline 304 & 76 & Chiradzulu & 1.13 & 0.64 & 9456 & 124.1 & 812 \\
\hline 305 & 203 & $\begin{array}{l}\text { Blantyre/Blantyre } \\
\text { City }\end{array}$ & 0.88 & 0.32 & 9408 & 46.3 & 6822 \\
\hline 306 & 233 & Mwanza & 1.44 & 0.56 & 4160 & 17.9 & 12595 \\
\hline 307 & 167 & Thyolo & 1.91 & 0.65 & 2689 & 16.1 & 3214 \\
\hline 308 & 201 & Mulanje & 1.55 & 0.69 & 523 & 2.6 & 8092 \\
\hline 309 & 143 & Phalombe & 1.35 & 0.62 & 8479 & 59.5 & na \\
\hline 310 & 490 & Chikwawa & 1.71 & 0.66 & 18663 & 38.1 & 14650 \\
\hline 311 & 195 & Nsanje & 1.41 & 0.76 & 6530 & 33.5 & 6569 \\
\hline 312 & 214 & Balaka & 1.09 & 0.67 & 8405 & 39.3 & na \\
\hline $\begin{array}{l}\text { Region } \\
\text { subtotal }\end{array}$ & 3300 & & & & 91992 & 27.9 & 101775 \\
\hline Total & 9590 & & & & 387698 & 40.4 & 461020 \\
\hline
\end{tabular}

@ From Government of Malawi (1993) 
Table 5 Fuelwood use, source, expenditure and collection time by households

\begin{tabular}{|c|c|c|c|c|c|c|c|c|}
\hline variable & $\begin{array}{l}\text { Non- } \\
\text { Poor }\end{array}$ & Poor & North & Center & South & $\begin{array}{l}\text { Less } \\
\text { biomass } \\
\text { Areas } \\
\end{array}$ & $\begin{array}{l}\text { More } \\
\text { Biomass } \\
\text { Areas }\end{array}$ & Overall \\
\hline \multicolumn{9}{|c|}{ Percent of households using fuelwood as cooking fuel: } \\
\hline Fuelwood is primary cooking fuel & $95.9 \%$ & $98.6 \%$ & $98.2 \%$ & $97.5 \%$ & $96.6 \%$ & $96.9 \%$ & $97.6 \%$ & $97.2 \%$ \\
\hline Fuelwood is secondary cooking fuel & $2.6 \%$ & $1.1 \%$ & $0.6 \%$ & $1.7 \%$ & $2.3 \%$ & $2.1 \%$ & $1.3 \%$ & $1.9 \%$ \\
\hline Fuelwood is primarily collected & $78.5 \%$ & $90.5 \%$ & $88.5 \%$ & $82.8 \%$ & $83.9 \%$ & $82.2 \%$ & $88.0 \%$ & $84.2 \%$ \\
\hline Fuelwood is sometimes collected & $7.8 \%$ & $5.4 \%$ & $2.6 \%$ & $7.2 \%$ & $7.4 \%$ & $7.9 \%$ & $4.2 \%$ & $6.6 \%$ \\
\hline \multicolumn{9}{|c|}{ Percent of households with different sources of fuelwood: } \\
\hline Own woodlot & $9.8 \%$ & $8.7 \%$ & $4.0 \%$ & $9.7 \%$ & $10.6 \%$ & $11.6 \%$ & $4.9 \%$ & $9.3 \%$ \\
\hline Community woodlot & $4.2 \%$ & $3.9 \%$ & $1.5 \%$ & $7.6 \%$ & $2.0 \%$ & $4.4 \%$ & $3.5 \%$ & $4.1 \%$ \\
\hline Forest reserve & $12.5 \%$ & $17.9 \%$ & $13.4 \%$ & $10.1 \%$ & $19.8 \%$ & $14.3 \%$ & $16.5 \%$ & $15.1 \%$ \\
\hline Unfarmed areas of community & $50.8 \%$ & $58.9 \%$ & $71.4 \%$ & $47.7 \%$ & $55.2 \%$ & $51.8 \%$ & $59.9 \%$ & $54.6 \%$ \\
\hline Other & $9.3 \%$ & $6.7 \%$ & $2.4 \%$ & $15.1 \%$ & $4.0 \%$ & $8.4 \%$ & $7.5 \%$ & $8.1 \%$ \\
\hline \multicolumn{9}{|l|}{ Distance, hours, and expenditure } \\
\hline One way walk to the source (Hours) & 0.6 & 0.6 & 0.5 & 0.7 & 0.6 & 0.6 & 0.6 & 0.6 \\
\hline $\begin{array}{l}\text { Hours spent (women) yesterday collecting } \\
\text { firewood }\end{array}$ & 1.5 & 1.5 & 1.2 & 1.5 & 1.5 & 1.5 & 1.5 & 1.5 \\
\hline Hours spent on agricultural activities per day & 2.9 & 2.8 & 2.7 & 2.8 & 3.0 & 2.9 & 2.8 & 2.9 \\
\hline Expenditure on Fuelwood (MK 2004) $^{@}$ & 3484 & 1536 & 1557 & 3205 & 2327 & 2731 & 2233 & 2558 \\
\hline Total Consumption Expenditure (MK 2004) ${ }^{@}$ & 31139 & 10946 & 21742 & 23809 & 19683 & 21850 & 21115 & 21595 \\
\hline Percent of Expenditure on Fuelwood & $11 \%$ & $14 \%$ & $7 \%$ & $13 \%$ & $12 \%$ & $12 \%$ & $11 \%$ & $12 \%$ \\
\hline \multicolumn{9}{|l|}{ Of those who collected fuelwood: } \\
\hline Percent women age 10 and above & $81.6 \%$ & $86.8 \%$ & $94.9 \%$ & $81.6 \%$ & $83.4 \%$ & $83.5 \%$ & $86.3 \%$ & $84.4 \%$ \\
\hline
\end{tabular}

$@$ Per capita per year. 
Table 6: Biomass and Per Capita Consumption Expenditure After Controlling for other Variables

\begin{tabular}{|l|r|r|r|r|}
\hline & Coeff Biomass & $\begin{array}{c}\text { Coeff Biomass } \\
\text { Squared }\end{array}$ & $\begin{array}{c}\text { Mean Biomass } \\
\text { (cum per ha) }\end{array}$ & Elasticity \\
\hline Overall & $0.0010209 * *$ & $-0.0000194 \quad * * *$ & 20.22 & $0.005 \%$ \\
\hline Non-Poor & 0.0000051 & -0.0000040 & 19.35 & \\
\hline Poor & $0.0015476 * * *$ & $-0.0000200 * * *$ & 21.20 & $0.01 \%$ \\
\hline Rural North & 0.0016728 & $-0.0000176 * *$ & 42.97 & \\
\hline Rural Center & -0.0001699 & -0.0000079 & 13.70 & \\
\hline Rural South & $0.0025929 * * *$ & $-0.0000347 \quad * * *$ & 18.61 & $0.02 \%$ \\
\hline
\end{tabular}

$@$ These numbers differ from Table 3 because of averaging differences. 
Table 7: Labor allocation for fuelwood collection by women 10 years and older

\begin{tabular}{|c|c|c|c|c|c|c|}
\hline & (1) Collect & (2) Hours & (3) Collect & (4) Hours & (5) Collect & (6) Hours \\
\hline & \multicolumn{2}{|c|}{ Overall } & \multicolumn{2}{|c|}{ Less Biomass } & \multicolumn{2}{|c|}{\begin{tabular}{l|l} 
& More Biomass
\end{tabular}} \\
\hline \multirow[t]{2}{*}{ Age in years } & $0.011^{* * *}$ & 0.009 & $0.008^{*}$ & 0.003 & $0.015^{* *}$ & 0.017 \\
\hline & $(0.004)$ & $(0.007)$ & $(0.005)$ & $(0.009)$ & $(0.006)$ & $(0.013)$ \\
\hline \multirow[t]{2}{*}{ Age Square } & $-0.0001 * * *$ & -0.0001 & $-0.0001 * *$ & -0.0001 & $-0.0002 * *$ & -0.0002 \\
\hline & $(0.0000)$ & $(0.0001)$ & $(0.0001)$ & $(0.0001)$ & $(0.0001)$ & $(0.0002)$ \\
\hline \multirow[t]{2}{*}{$\begin{array}{l}\text { Head Education: Snr. } \\
\text { Prim or more }\end{array}$} & $-0.053 * *$ & $0.088 *$ & $-0.073^{* *}$ & $0.110 *$ & -0.012 & 0.009 \\
\hline & $(0.026)$ & $(0.049)$ & $(0.033)$ & $(0.062)$ & $(0.045)$ & $(0.085)$ \\
\hline \multirow[t]{2}{*}{ HH Size } & $-0.014 * * *$ & 0.015 & $-0.021 * * *$ & -0.003 & 0.004 & $0.038 * *$ \\
\hline & $(0.005)$ & $(0.010)$ & $(0.006)$ & $(0.012)$ & $(0.009)$ & $(0.016)$ \\
\hline \multirow[t]{2}{*}{$\begin{array}{l}\text { Real Value of Assets } \\
\text { '000 }\end{array}$} & $-0.002 * * *$ & 0.000 & $-0.003 * * *$ & 0.002 & $-0.001^{*}$ & -0.001 \\
\hline & $(0.001)$ & $(0.001)$ & $(0.001)$ & $(0.002)$ & $(0.001)$ & $(0.002)$ \\
\hline \multirow[t]{2}{*}{$\begin{array}{l}\text { Wet Season \& Wet } \\
\text { Area Interaction }\end{array}$} & 0.009 & 0.042 & 0.003 & 0.056 & 0.026 & -0.014 \\
\hline & $(0.021)$ & $(0.044)$ & $(0.024)$ & $(0.051)$ & $(0.041)$ & $(0.088)$ \\
\hline \multirow[t]{2}{*}{$\begin{array}{l}\text { Dry Season and Dimba } \\
\text { Area Interaction }\end{array}$} & $0.153 * *$ & -0.150 & 0.068 & -0.105 & $0.312 * * *$ & -0.251 \\
\hline & $(0.065)$ & $(0.108)$ & $(0.081)$ & $(0.148)$ & $(0.121)$ & $(0.174)$ \\
\hline \multirow[t]{2}{*}{$\begin{array}{l}\text { Owned \& uncultivated } \\
\text { last season }\end{array}$} & $0.117 * * *$ & 0.021 & $0.129 * * *$ & 0.084 & $0.090 * * *$ & -0.052 \\
\hline & $(0.021)$ & $(0.040)$ & $(0.031)$ & $(0.055)$ & $(0.030)$ & $(0.061)$ \\
\hline \multirow[t]{2}{*}{ Total hectares of trees } & 0.259 & -0.378 & $1.392 * *$ & -0.776 & -0.124 & 0.229 \\
\hline & $(0.259)$ & $(0.449)$ & $(0.549)$ & $(0.663)$ & $(0.344)$ & $(0.666)$ \\
\hline \multirow[t]{2}{*}{$\begin{array}{l}\text { Predicted Real Avg } \\
\text { Wage for Women }\end{array}$} & $-0.001 * * *$ & 0.001 & $-0.001 * * *$ & 0.000 & $-0.001 * *$ & $0.002 *$ \\
\hline & $(0.000)$ & $(0.001)$ & $(0.000)$ & $(0.001)$ & $(0.000)$ & $(0.001)$ \\
\hline \multirow[t]{2}{*}{$\begin{array}{l}\text { Number of }<5 y r \\
\text { children }\end{array}$} & $0.076 * * *$ & $-0.075 * *$ & $0.095 * * *$ & -0.053 & 0.038 & -0.085 \\
\hline & $(0.020)$ & $(0.036)$ & $(0.024)$ & $(0.046)$ & $(0.034)$ & $(0.061)$ \\
\hline \multirow[t]{2}{*}{ Married for age $12+$} & $0.175 * * *$ & -0.074 & $0.201 * * *$ & -0.049 & $0.147 * * *$ & $-0.176^{*}$ \\
\hline & $(0.031)$ & $(0.063)$ & $(0.038)$ & $(0.080)$ & $(0.053)$ & $(0.106)$ \\
\hline \multirow[t]{2}{*}{ Rural Centre } & -0.033 & $0.359 * * *$ & 0.020 & $0.278 * *$ & 0.019 & $0.388 * * *$ \\
\hline & $(0.045)$ & $(0.085)$ & $(0.063)$ & $(0.119)$ & $(0.072)$ & $(0.139)$ \\
\hline \multirow[t]{2}{*}{ Rural South } & -0.073 & $0.410^{* * *}$ & 0.088 & $0.322 * * *$ & $-0.206 * * *$ & $0.489 * * *$ \\
\hline & $(0.045)$ & $(0.083)$ & $(0.065)$ & $(0.125)$ & $(0.066)$ & $(0.137)$ \\
\hline \multirow[t]{2}{*}{ Wet Season Dummy } & $-0.105 * * *$ & -0.001 & $-0.107 * * *$ & -0.046 & $-0.120 * *$ & 0.179 \\
\hline & $(0.032)$ & $(0.064)$ & $(0.040)$ & $(0.079)$ & $(0.058)$ & $(0.122)$ \\
\hline \multirow[t]{2}{*}{$\begin{array}{l}\text { ADMARC Market } \\
\text { Distance KM }\end{array}$} & 0.0002 & $0.0011^{* *}$ & 0.0003 & $0.0010^{* *}$ & -0.0020 & $0.0091 * * *$ \\
\hline & $(0.0003)$ & $(0.0005)$ & $(0.0003)$ & $(0.0005)$ & $(0.0015)$ & $(0.0029)$ \\
\hline \multirow[t]{2}{*}{$\begin{array}{l}\text { Distance to Asphalt } \\
\text { Road KM }\end{array}$} & $-0.0011^{* * * *}$ & 0.0004 & 0.0005 & -0.0017 & $-0.0018 * * *$ & 0.0014 \\
\hline & $(0.0004)$ & $(0.0009)$ & $(0.0005)$ & $(0.0013)$ & $(0.0007)$ & $(0.0015)$ \\
\hline \multirow[t]{2}{*}{ Elevation } & $-0.00010^{* *}$ & -0.00004 & 0.00000 & -0.00007 & $-0.00029 * * *$ & 0.00011 \\
\hline & $(0.00004)$ & $(0.00008)$ & $(0.00005)$ & $(0.00011)$ & $(0.00008)$ & $(0.00016)$ \\
\hline \multirow[t]{2}{*}{ Biomass (m3/ha) } & 0.001** & -0.001 & $0.009 * * *$ & $-0.018 * * *$ & $0.005 * * *$ & $-0.006 * * *$ \\
\hline & $(0.001)$ & $(0.001)$ & $(0.003)$ & $(0.005)$ & $(0.001)$ & $(0.002)$ \\
\hline \multirow[t]{2}{*}{$\begin{array}{l}\text { Price of Maize Grain } \\
\mathrm{MK} / \mathrm{Kg}\end{array}$} & 0.002 & -0.018 & -0.011 & -0.015 & $0.020 *$ & -0.026 \\
\hline & $(0.006)$ & $(0.013)$ & $(0.008)$ & $(0.016)$ & $(0.011)$ & $(0.023)$ \\
\hline Recent illness/injury & 0.023 & $-0.084^{*}$ & 0.035 & -0.061 & 0.013 & -0.135 \\
\hline & $(0.027)$ & $(0.050)$ & $(0.034)$ & $(0.062)$ & $(0.047)$ & $(0.089)$ \\
\hline $\begin{array}{l}\text { Do you suffer from a } \\
\text { chronic illness }\end{array}$ & -0.035 & $-0.149 * *$ & -0.026 & $-0.188 * *$ & -0.047 & -0.122 \\
\hline & $(0.040)$ & $(0.075)$ & $(0.048)$ & $(0.088)$ & $(0.072)$ & $(0.144)$ \\
\hline
\end{tabular}




\begin{tabular}{|c|c|c|c|c|c|c|}
\hline $\begin{array}{l}\text { Other Members } \\
\text { Chronically Ill in } \mathrm{HH}\end{array}$ & $\begin{array}{l}-0.031^{*} \\
(0.018) \\
\end{array}$ & $\begin{array}{l}-0.086^{* * *} \\
(0.034) \\
\end{array}$ & $\begin{array}{l}-0.027 \\
(0.022) \\
\end{array}$ & $\begin{array}{l}-0.085^{* *} \\
(0.040) \\
\end{array}$ & $\begin{array}{l}-0.031 \\
(0.031) \\
\end{array}$ & $\begin{array}{l}-0.081 \\
(0.062) \\
\end{array}$ \\
\hline $\begin{array}{l}\text { Substitute for collected } \\
\text { fuelwood }\end{array}$ & $-0.536 * * *$ & & $-0.472 * * *$ & & $-0.732 * * *$ & \\
\hline & $(0.041)$ & & $(0.047)$ & & $(0.088)$ & \\
\hline Constant & $-0.596 * * *$ & $1.674 * * *$ & $-0.562 * * *$ & $1.848^{* * *}$ & $-1.031 * * *$ & $2.145^{* * *}$ \\
\hline & $(0.145)$ & $(0.383)$ & $(0.185)$ & $(0.485)$ & $(0.247)$ & $(0.736)$ \\
\hline Observations & 13281 & 13281 & 8690 & 8690 & 4591 & 4591 \\
\hline & & -0.244 & & -0.135 & & $-0.688^{*}$ \\
\hline Inverse Mills Ratio & & $(0.214)$ & & $(0.270)$ & & $(0.359)$ \\
\hline
\end{tabular}

Standard errors in parentheses * significant at $10 \%$; ** significant at $5 \%$; ** significant at $1 \%$ 
Table 8: Labor allocation hours for household agriculture by women 10 years and older

\begin{tabular}{|c|c|c|c|}
\hline & $(1)$ & $(2)$ & (3) \\
\hline & Overall & Less Biomass Areas & More Biomass Areas \\
\hline \multirow[t]{2}{*}{ Age in years } & $0.133 * * *$ & $0.138 * * *$ & $0.126 * * *$ \\
\hline & $(0.007)$ & $(0.008)$ & $(0.011)$ \\
\hline \multirow[t]{2}{*}{ Age Square } & $-0.001 * * *$ & $-0.001^{* * *}$ & $-0.001^{* * *}$ \\
\hline & $(0.000)$ & $(0.000)$ & $(0.000)$ \\
\hline \multirow[t]{2}{*}{ Head Education: Snr. Prim or more } & $-0.142 * * *$ & -0.029 & $-0.360 * * *$ \\
\hline & $(0.048)$ & $(0.059)$ & $(0.082)$ \\
\hline \multirow[t]{2}{*}{ HH Size } & $-0.031^{* * *}$ & $-0.038 * * *$ & $-0.042^{* *}$ \\
\hline & $(0.010)$ & $(0.012)$ & $(0.017)$ \\
\hline \multirow[t]{2}{*}{ Real Value of Assets '000 } & $-0.005 * * *$ & $-0.005 * * *$ & $-0.004 * * *$ \\
\hline & $(0.001)$ & $(0.001)$ & $(0.001)$ \\
\hline \multirow[t]{2}{*}{ Wet Season \& Wet Area Interaction } & $0.181^{* * *}$ & $0.176^{* * *}$ & $0.229 * * *$ \\
\hline & $(0.036)$ & $(0.041)$ & $(0.074)$ \\
\hline \multirow[t]{2}{*}{ Dry Season and Dimba Area Interaction } & $0.623^{* * *}$ & $0.582 * * *$ & $0.596 * * *$ \\
\hline & $(0.121)$ & $(0.144)$ & $(0.220)$ \\
\hline \multirow[t]{2}{*}{ Owned \& uncultivated last season } & $-0.150 * * *$ & -0.090 & $-0.167 * * *$ \\
\hline & $(0.043)$ & $(0.061)$ & $(0.061)$ \\
\hline \multirow[t]{2}{*}{ Total hectares of trees } & 0.224 & 1.041 & 0.184 \\
\hline & $(0.479)$ & $(0.934)$ & $(0.559)$ \\
\hline \multirow[t]{2}{*}{ Predicted Real Avg Wage for Women } & $-0.003 * * *$ & $-0.003 * * *$ & $-0.003 * * *$ \\
\hline & $(0.000)$ & $(0.001)$ & $(0.001)$ \\
\hline \multirow[t]{2}{*}{ Number of $<5$ yr children } & $0.256 * * *$ & $0.245 * * *$ & $0.289 * * *$ \\
\hline & $(0.036)$ & $(0.043)$ & $(0.061)$ \\
\hline \multirow[t]{2}{*}{ Married for age $12+$} & $0.563 * * *$ & $0.585 * * *$ & $0.462 * * *$ \\
\hline & $(0.055)$ & $(0.067)$ & $(0.094)$ \\
\hline \multirow[t]{2}{*}{ Rural Centre } & -0.036 & $-0.385 * * *$ & $0.514^{* * *}$ \\
\hline & $(0.081)$ & $(0.109)$ & $(0.129)$ \\
\hline \multirow[t]{2}{*}{ Rural South } & -0.032 & $-0.455^{* * *}$ & $0.340 * * *$ \\
\hline & $(0.082)$ & $(0.113)$ & $(0.123)$ \\
\hline \multirow[t]{2}{*}{ Wet Season Dummy } & $0.740 * * *$ & $0.642 * * *$ & $0.891 * * *$ \\
\hline & $(0.058)$ & $(0.071)$ & $(0.104)$ \\
\hline \multirow[t]{2}{*}{ ADMARC Market Distance KM } & $0.003 * * *$ & $0.002^{* * *}$ & $0.016^{* * *}$ \\
\hline & $(0.000)$ & $(0.000)$ & $(0.003)$ \\
\hline \multirow[t]{2}{*}{ Distance to Asphalt Road KM } & $0.006 * * *$ & 0.001 & $0.010 * * *$ \\
\hline & $(0.001)$ & $(0.001)$ & $(0.001)$ \\
\hline \multirow[t]{2}{*}{ Elevation } & $-0.000 * * *$ & $-0.001 * * *$ & 0.000 \\
\hline & $(0.000)$ & $(0.000)$ & $(0.000)$ \\
\hline \multirow[t]{2}{*}{ Biomass (m3/ha) } & $-0.005 * * *$ & 0.003 & 0.000 \\
\hline & $(0.001)$ & $(0.005)$ & $(0.002)$ \\
\hline \multirow[t]{2}{*}{ Price of Maize Grain MK/Kg } & $0.045^{* * *}$ & $0.085 * * *$ & 0.000 \\
\hline & $(0.012)$ & $(0.015)$ & $(0.019)$ \\
\hline \multirow[t]{2}{*}{ Recent illness/injury } & $-0.215^{* * *}$ & $-0.213^{* * *}$ & $-0.209 * *$ \\
\hline & $(0.049)$ & $(0.060)$ & $(0.083)$ \\
\hline Do you suffer from a chronic illness & $-0.176 * *$ & $-0.219 * * *$ & -0.172 \\
\hline & $(0.070)$ & $(0.085)$ & $(0.125)$ \\
\hline Other Members Chronically Ill in HH & $-0.153 * * *$ & $-0.113 * * *$ & $-0.282 * * *$ \\
\hline & $(0.032)$ & $(0.038)$ & $(0.057)$ \\
\hline Productive Assets Index & $8.078 * * *$ & $6.945 * * *$ & $11.463 * * *$ \\
\hline & $(0.831)$ & $(0.952)$ & $(1.709)$ \\
\hline Constant & $-2.028 * * *$ & $-2.156 * * *$ & $-2.388 * * *$ \\
\hline & $(0.262)$ & $(0.330)$ & $(0.437)$ \\
\hline Observations & 12740 & 8399 & 4341 \\
\hline
\end{tabular}

Standard errors in parentheses * significant at 10\%; ** significant at $5 \%$; *** significant at $1 \%$ 


\begin{tabular}{|c|c|c|c|c|c|c|}
\hline & $(1)$ & $(2)$ & $(3)$ & $(4)$ & $(5)$ & $(6)$ \\
\hline & Rural & Non-Poor & Poor & North & Central & South \\
\hline \multirow[t]{2}{*}{ Female household head } & -0.148 & -0.104 & -0.061 & -0.117 & -0.149 & -0.158 \\
\hline & {$[0.014]^{* * *}$} & {$[0.017]^{* * *}$} & {$[0.013]^{* * *}$} & {$[0.041]^{* * *}$} & {$[0.022]^{* * *}$} & {$[0.020]^{* * *}$} \\
\hline \multirow{2}{*}{ Age of hh head: $26-35$ years } & 0.058 & 0.049 & 0.026 & 0.032 & 0.053 & 0.059 \\
\hline & {$[0.017]^{* * *}$} & {$[0.017]^{* * *}$} & {$[0.015]^{*}$} & {$[0.045]$} & {$[0.025]^{* *}$} & {$[0.025]^{* *}$} \\
\hline \multirow{2}{*}{ Age of hh head: $36-45$ years } & 0.072 & 0.064 & 0.024 & 0.029 & 0.028 & 0.118 \\
\hline & {$[0.019]^{* * *}$} & {$[0.020]^{* * *}$} & {$[0.017]$} & {$[0.049]$} & {$[0.028]$} & {$[0.028]^{* * *}$} \\
\hline \multirow[t]{2}{*}{ Age of hh head: $46-55$ years } & 0.010 & 0.016 & 0.014 & -0.029 & -0.018 & 0.041 \\
\hline & {$[0.019]$} & {$[0.021]$} & {$[0.018]$} & {$[0.053]$} & {$[0.030]$} & {$[0.028]$} \\
\hline \multirow{2}{*}{ Age of hh head: $56-65$ years } & -0.053 & -0.039 & -0.029 & -0.026 & -0.102 & -0.024 \\
\hline & {$[0.020]^{* * *}$} & {$[0.022]^{*}$} & {$[0.019]$} & {$[0.055]$} & {$[0.032]^{* * *}$} & {$[0.029]$} \\
\hline \multirow{2}{*}{ Age of hh head: $66+$ years } & -0.099 & -0.069 & -0.023 & -0.032 & -0.134 & -0.091 \\
\hline & {$[0.022]^{* * *}$} & {$[0.023]^{* * *}$} & {$[0.020]$} & {$[0.056]$} & {$[0.032]^{* * *}$} & {$[0.033]^{* * *}$} \\
\hline \multirow[t]{2}{*}{ Widowed household head } & 0.058 & 0.053 & 0.028 & 0.079 & 0.039 & 0.052 \\
\hline & {$[0.019]^{* * *}$} & {$[0.023]^{* *}$} & {$[0.017]^{*}$} & {$[0.056]$} & {$[0.028]$} & {$[0.028]^{*}$} \\
\hline \multirow[t]{2}{*}{ Household size } & -0.290 & -0.216 & -0.090 & -0.255 & -0.299 & -0.301 \\
\hline & {$[0.025]^{* * *}$} & {$[0.013]^{* * *}$} & {$[0.013]^{* * *}$} & {$[0.028]^{* * *}$} & {$[0.014]^{* * *}$} & {$[0.042]^{* * *}$} \\
\hline \multirow[t]{2}{*}{ Household size squared (/100) } & 1.313 & 1.182 & 0.288 & 1.079 & 1.461 & 1.286 \\
\hline & {$[0.208]^{* * *}$} & {$[0.103]^{* * *}$} & {$[0.092]^{* * *}$} & {$[0.209]^{* * *}$} & {$[0.097]^{* * *}$} & {$[0.361]^{* * *}$} \\
\hline \multirow[t]{2}{*}{ Number of children 0-4 } & -0.059 & -0.032 & -0.027 & -0.061 & -0.047 & -0.060 \\
\hline & {$[0.009]^{* * *}$} & {$[0.010]^{* * *}$} & {$[0.008]^{* * *}$} & {$[0.024]^{* *}$} & {$[0.013]^{* * *}$} & {$[0.015]^{* * *}$} \\
\hline \multirow[t]{2}{*}{ Number of children 5-10 } & -0.028 & 0.012 & -0.017 & -0.002 & -0.029 & -0.028 \\
\hline & {$[0.009]^{* * *}$} & {$[0.010]$} & {$[0.007]^{* *}$} & {$[0.021]$} & {$[0.012]^{* *}$} & {$[0.014]^{* *}$} \\
\hline \multirow[t]{2}{*}{ Number of children 11-14 } & -0.001 & 0.015 & -0.003 & -0.005 & -0.013 & 0.012 \\
\hline & {$[0.010]$} & {$[0.012]$} & {$[0.008]$} & {$[0.025]$} & {$[0.014]$} & {$[0.016]$} \\
\hline \multirow{2}{*}{$\begin{array}{l}\text { Highest education: some } \\
\text { primary }\end{array}$} & 0.064 & 0.030 & 0.081 & -0.057 & 0.072 & 0.064 \\
\hline & {$[0.022]^{* * *}$} & {$[0.021]$} & {$[0.019]^{* * *}$} & {$[0.109]$} & {$[0.030]^{* *}$} & {$[0.030]^{* *}$} \\
\hline \multirow{2}{*}{$\begin{array}{l}\text { Highest education: completed } \\
\text { primary }\end{array}$} & 0.161 & 0.101 & 0.122 & -0.072 & 0.196 & 0.176 \\
\hline & {$[0.026]^{* * *}$} & {$[0.025]^{* * *}$} & {$[0.022]^{* * *}$} & {$[0.112]$} & {$[0.036]^{* * *}$} & {$[0.036]^{* * *}$} \\
\hline \multirow{2}{*}{$\begin{array}{l}\text { Highest education: post } \\
\text { primary }\end{array}$} & 0.364 & 0.219 & 0.194 & 0.074 & 0.357 & 0.443 \\
\hline & {$[0.026]^{* * *}$} & {$[0.025]^{* * *}$} & {$[0.022]^{* * *}$} & {$[0.112]$} & {$[0.035] * * *$} & {$[0.037]^{* * *}$} \\
\hline \multirow[t]{2}{*}{ Chronic illness in household } & 0.059 & 0.021 & 0.034 & -0.033 & 0.046 & 0.082 \\
\hline & {$[0.011]^{* * *}$} & {$[0.012]^{*}$} & {$[0.010]^{* * *}$} & {$[0.036]$} & {$[0.015]^{* * *}$} & {$[0.016]^{* * *}$} \\
\hline \multirow[t]{2}{*}{ Religion: Islam } & -0.001 & -0.008 & -0.014 & 0.113 & 0.024 & 0.010 \\
\hline & {$[0.025]$} & {$[0.028]$} & {$[0.021]$} & {$[0.157]$} & {$[0.038]$} & {$[0.043]$} \\
\hline \multirow[t]{2}{*}{ Religion: Catholic } & -0.001 & -0.018 & -0.039 & -0.103 & 0.017 & -0.008 \\
\hline & {$[0.021]$} & {$[0.023]$} & {$[0.018]^{* *}$} & {$[0.095]$} & {$[0.025]$} & {$[0.040]$} \\
\hline \multirow[t]{2}{*}{ Religion: CCAP } & 0.061 & 0.019 & -0.022 & -0.082 & 0.083 & 0.083 \\
\hline & {$[0.022]^{* * *}$} & {$[0.024]$} & {$[0.020]$} & {$[0.092]$} & {$[0.028]^{* * *}$} & {$[0.045]^{*}$} \\
\hline \multirow[t]{2}{*}{ Religion: Other Christian } & -0.000 & -0.021 & -0.025 & -0.117 & 0.008 & -0.004 \\
\hline & {$[0.019]$} & {$[0.021]$} & {$[0.017]$} & {$[0.090]$} & {$[0.023]$} & {$[0.038]$} \\
\hline \multirow[t]{2}{*}{ HH has wage/salary income } & 0.114 & 0.060 & 0.052 & 0.117 & 0.107 & 0.113 \\
\hline & {$[0.011]^{* * *}$} & {$[0.013]^{* * *}$} & {$[0.010]^{* * *}$} & {$[0.036]^{* * *}$} & {$[0.017]^{* * *}$} & {$[0.016]^{* * *}$} \\
\hline \multirow{2}{*}{$\begin{array}{l}\text { Household has a non-farm } \\
\text { enterprise }\end{array}$} & 0.142 & 0.053 & 0.066 & 0.181 & 0.136 & 0.134 \\
\hline & {$[0.011]^{* * *}$} & {$[0.012]^{* * *}$} & {$[0.010]^{* * *}$} & {$[0.030]^{* * *}$} & {$[0.017]^{* * *}$} & {$[0.015]^{* * *}$} \\
\hline $\begin{array}{l}\text { HH grew tobacco in last } \\
\text { cropping season }\end{array}$ & 0.072 & 0.032 & 0.007 & 0.107 & 0.079 & 0.029 \\
\hline
\end{tabular}




\begin{tabular}{|c|c|c|c|c|c|c|}
\hline & {$[0.015]^{* * *}$} & {$[0.015]^{* *}$} & {$[0.013]$} & {$[0.033]^{* * *}$} & {$[0.020]^{* * *}$} & [0.032] \\
\hline \multirow[t]{2}{*}{ Total hectares of dimba plots } & 0.073 & 0.044 & 0.049 & 0.037 & 0.066 & 0.101 \\
\hline & {$[0.023]^{* * *}$} & {$[0.023]^{*}$} & {$[0.018]^{* * *}$} & [0.029] & {$[0.027]^{* *}$} & [0.059]* \\
\hline \multirow[t]{2}{*}{ Total hectares of rain-fed plots } & 0.111 & 0.066 & 0.051 & 0.112 & 0.126 & 0.086 \\
\hline & {$[0.007]^{* * *}$} & {$[0.007]^{* * *}$} & {$[0.008]^{* * *}$} & {$[0.017]^{* * *}$} & {$[0.010]^{* * *}$} & {$[0.011]^{* * *}$} \\
\hline \multirow[t]{2}{*}{$\begin{array}{l}\text { Regular bus service in } \\
\text { community }\end{array}$} & 0.006 & 0.008 & -0.020 & -0.006 & -0.027 & 0.011 \\
\hline & {$[0.012]$} & {$[0.013]$} & \begin{tabular}{|l}
{$[0.010]^{*}$} \\
\end{tabular} & {$[0.032]$} & {$[0.018]$} & {$[0.018]$} \\
\hline \multirow[t]{2}{*}{ Health clinic in community } & 0.061 & 0.030 & 0.051 & 0.069 & 0.099 & 0.032 \\
\hline & {$[0.011]^{* * *}$} & {$[0.012]^{* *}$} & {$[0.010]^{* * *}$} & {$[0.029]^{* *}$} & {$[0.018]^{* * *}$} & {$[0.016]^{* *}$} \\
\hline \multirow[t]{2}{*}{$\begin{array}{l}\text { EA is a Boma or Trading } \\
\text { center }\end{array}$} & 0.203 & 0.169 & 0.046 & 0.331 & 0.242 & 0.137 \\
\hline & {$[0.025]^{* * *}$} & {$[0.026]^{* * *}$} & {$[0.023]^{* *}$} & {$[0.068]^{* * *}$} & {$[0.043]^{* * *}$} & {$[0.036]^{* * *}$} \\
\hline \multirow{2}{*}{$\begin{array}{l}\text { Travel to nearest boma: }>20 \text { - } \\
\text { 30mins }\end{array}$} & -0.009 & -0.030 & 0.021 & 0.007 & 0.073 & -0.057 \\
\hline & {$[0.016]$} & {$[0.018]^{*}$} & {$[0.014]$} & [0.055] & {$[0.026]^{* * *}$} & {$[0.023]^{* *}$} \\
\hline \multirow{2}{*}{$\begin{array}{l}\text { Travel to nearest boma: }>30- \\
45 \mathrm{mins}\end{array}$} & -0.102 & -0.058 & -0.027 & -0.267 & -0.008 & -0.103 \\
\hline & {$[0.016]^{* * *}$} & {$[0.018]^{* * *}$} & {$[0.013]^{* *}$} & {$[0.050]^{* * *}$} & [0.022] & {$[0.024]^{* * *}$} \\
\hline \multirow{2}{*}{$\begin{array}{l}\text { Travel to nearest boma: }>45- \\
60 \mathrm{mins}\end{array}$} & -0.039 & -0.020 & -0.025 & -0.278 & 0.074 & -0.044 \\
\hline & {$[0.017]^{* *}$} & [0.019] & {$[0.015]^{*}$} & {$[0.052]^{* * *}$} & {$[0.024]^{* * *}$} & {$[0.027]^{*}$} \\
\hline \multirow{2}{*}{$\begin{array}{l}\text { Travel to nearest boma: } \\
\text { >60mins }\end{array}$} & -0.018 & -0.007 & 0.000 & -0.128 & 0.103 & -0.068 \\
\hline & {$[0.017]$} & [0.019] & {$[0.014]$} & {$[0.052]^{* *}$} & {$[0.028] * * *$} & {$[0.024]^{* * *}$} \\
\hline \multirow{2}{*}{$\begin{array}{l}\text { ADMARC market in the } \\
\text { community }\end{array}$} & -0.050 & -0.035 & -0.032 & 0.032 & -0.077 & -0.049 \\
\hline & {$[0.014]^{* * *}$} & {$[0.016]^{* *}$} & {$[0.013]^{* *}$} & [0.044] & {$[0.024] * * *$} & {$[0.020]^{* *}$} \\
\hline \multirow[t]{2}{*}{ Bank in community } & -0.014 & -0.032 & 0.004 & 0.423 & -0.042 & -0.017 \\
\hline & {$[0.022]$} & {$[0.025]$} & {$[0.020]$} & {$[0.096]^{* * *}$} & {$[0.035]$} & {$[0.032]$} \\
\hline \multirow[t]{2}{*}{ Daily market in community } & 0.004 & 0.039 & -0.004 & -0.077 & 0.047 & 0.014 \\
\hline & [0.013] & {$[0.015]^{* * *}$} & {$[0.011]$} & {$[0.037]^{* *}$} & {$[0.024]^{* *}$} & [0.018] \\
\hline \multirow{2}{*}{$\begin{array}{l}\text { Tarmac/asphalt road in } \\
\text { community }\end{array}$} & 0.029 & 0.016 & 0.045 & -0.194 & 0.194 & -0.003 \\
\hline & {$[0.017]^{*}$} & {$[0.020]$} & {$[0.015]^{* * *}$} & {$[0.044]^{* * *}$} & {$[0.032]^{* * *}$} & {$[0.025]$} \\
\hline \multirow[t]{2}{*}{ Biomass (m3/ha) } & 0.0010209 & 0.0000051 & 0.0015476 & 0.0016728 & -0.00017 & 0.0025929 \\
\hline & {$[0.001]^{* *}$} & {$[0.001]$} & {$[0.0004]^{* * *}$} & {$[0.001]$} & [0.001] & {$[0.001]^{* * *}$} \\
\hline \multirow[t]{2}{*}{ Biomass / Ha Squared } & -0.0000194 & -0.000004 & -0.00002 & -0.000018 & -0.000008 & -0.000035 \\
\hline & $\begin{array}{l}{[0.000005]^{*}} \\
* *\end{array}$ & {$[0.000007]$} & $\begin{array}{l}{[0.000005]^{*}} \\
* *\end{array}$ & {$[0.00001]^{*}$} & [0.000009] & $\begin{array}{l}{[0.000008]^{*}} \\
* *\end{array}$ \\
\hline \multirow[t]{2}{*}{ North region } & 0.007 & & & & & \\
\hline & [0.029] & & & & & \\
\hline \multirow[t]{2}{*}{ Central region } & 0.270 & & & & & \\
\hline & {$[0.022]^{* * *}$} & & & & & \\
\hline \multirow[t]{2}{*}{ ADD: Karonga } & & 0.016 & 0.012 & -0.097 & & \\
\hline & & {$[0.034]$} & {$[0.024]$} & {$[0.032]^{* * *}$} & & \\
\hline \multirow[t]{2}{*}{ ADD: Mzuzu } & 0.113 & 0.077 & 0.042 & & & \\
\hline & {$[0.028]^{* * *}$} & {$[0.029]^{* * *}$} & {$[0.022]^{*}$} & & & \\
\hline \multirow[t]{2}{*}{ ADD: Kasungu } & & 0.080 & 0.215 & & 0.133 & \\
\hline & & {$[0.025]^{* * *}$} & {$[0.021]^{* * *}$} & & {$[0.027]^{* * *}$} & \\
\hline \multirow[t]{2}{*}{ ADD: Salima } & -0.088 & 0.054 & 0.119 & & & \\
\hline & {$[0.024]^{* * *}$} & {$[0.030]^{*}$} & {$[0.024]^{* * *}$} & & & \\
\hline \multirow[t]{2}{*}{ ADD: Lilongwe } & -0.043 & 0.128 & 0.080 & & 0.092 & \\
\hline & {$[0.017]^{* * *}$} & {$[0.024] * * *$} & {$[0.019]^{* * *}$} & & {$[0.026]^{* * *}$} & \\
\hline
\end{tabular}




\begin{tabular}{|l|l|l|l|l|l|l|}
\hline ADD: Machinga & -0.047 & 0.005 & -0.055 & & & -0.053 \\
\hline & {$[0.023]^{* *}$} & {$[0.027]$} & {$[0.020]^{* * *}$} & & & {$[0.025]^{* *}$} \\
\hline ADD: Blantyre & 0.004 & 0.023 & 0.003 & & & -0.012 \\
\hline & {$[0.021]$} & {$[0.025]$} & {$[0.018]$} & & & {$[0.022]$} \\
\hline Observations & 9752 & 5140 & 4612 & 1415 & 3819 & 4518 \\
\hline R-squared & 0.44 & 0.26 & 0.21 & 0.43 & 0.45 & 0.44 \\
\hline
\end{tabular}

Robust standard errors in parentheses * significant at 10\%; ** significant at 5\%; *** significant at $1 \%$ 


\begin{tabular}{|c|c|c|c|c|c|c|}
\hline \multirow[t]{2}{*}{ Male } & (1) Collect & (2) Hours & (3) Collect & (4) Hours & (5) Collect & (6) Hours \\
\hline & \multicolumn{2}{|c|}{ Overall } & \multicolumn{2}{|c|}{ Less Biomass } & \multicolumn{2}{|c|}{ More Biomass } \\
\hline \multirow[t]{2}{*}{ Age in years } & 0.002 & 0.053* & -0.003 & $0.079 * *$ & 0.013 & 0.005 \\
\hline & $(0.009)$ & $(0.029)$ & $(0.010)$ & $(0.039)$ & $(0.015)$ & $(0.037)$ \\
\hline \multirow[t]{2}{*}{ Age Square } & 0.0000 & $-0.0006 *$ & 0.0001 & $-0.0009 * *$ & -0.0001 & 0.0000 \\
\hline & $(0.0001)$ & $(0.0003)$ & $(0.0001)$ & $(0.0004)$ & $(0.0002)$ & $(0.0004)$ \\
\hline \multirow[t]{2}{*}{ Head Education: Snr. Prim or more } & $-0.092 * *$ & -0.151 & -0.054 & -0.028 & $-0.169 * *$ & $-0.419 *$ \\
\hline & $(0.045)$ & $(0.161)$ & $(0.054)$ & $(0.205)$ & $(0.083)$ & $(0.232)$ \\
\hline \multirow[t]{2}{*}{ HH Size } & $-0.040 * * *$ & -0.051 & $-0.036 * * *$ & -0.048 & $-0.052 * * *$ & -0.055 \\
\hline & $(0.009)$ & $(0.041)$ & $(0.011)$ & $(0.055)$ & $(0.017)$ & $(0.052)$ \\
\hline \multirow[t]{2}{*}{ Real Value of Assets ' 000} & -0.002 & -0.003 & -0.002 & 0.000 & -0.006 & -0.015 \\
\hline & $(0.001)$ & $(0.006)$ & $(0.001)$ & $(0.007)$ & $(0.005)$ & $(0.016)$ \\
\hline \multirow[t]{2}{*}{ Wet Season \& Wet Area Interaction } & 0.009 & 0.123 & -0.053 & -0.032 & $0.148^{* *}$ & $0.336^{* *}$ \\
\hline & $(0.033)$ & $(0.099)$ & $(0.043)$ & $(0.177)$ & $(0.058)$ & $(0.149)$ \\
\hline \multirow[t]{2}{*}{ Dry Season and Dimba Area Interaction } & 0.144 & -0.121 & 0.127 & -0.163 & 0.207 & -0.334 \\
\hline & $(0.093)$ & $(0.269)$ & $(0.105)$ & $(0.311)$ & $(0.205)$ & $(0.616)$ \\
\hline \multirow[t]{2}{*}{ Total hectares of land uncultivated } & 0.038 & 0.207 & 0.050 & 0.190 & 0.011 & $0.361 *$ \\
\hline & $(0.038)$ & $(0.131)$ & $(0.051)$ & $(0.166)$ & $(0.067)$ & $(0.194)$ \\
\hline \multirow[t]{2}{*}{ Total hectares of trees } & 0.081 & 0.364 & 0.439 & 1.040 & -0.965 & -3.707 \\
\hline & $(0.408)$ & $(1.471)$ & $(0.468)$ & $(1.816)$ & (0.951) & (2.563) \\
\hline \multirow[t]{2}{*}{ Predicted Real Wage for Women } & -0.001 & -0.002 & 0.000 & -0.002 & 0.000 & -0.001 \\
\hline & $(0.001)$ & $(0.002)$ & $(0.001)$ & $(0.003)$ & $(0.001)$ & $(0.002)$ \\
\hline \multirow[t]{2}{*}{ Number of $<$ yyr children } & 0.077 & -0.009 & 0.131 & 0.048 & -0.122 & -0.634 \\
\hline & $(0.118)$ & $(0.420)$ & $(0.131)$ & $(0.517)$ & $(0.276)$ & $(0.707)$ \\
\hline \multirow[t]{2}{*}{ Married } & $-0.468 * * *$ & -0.368 & $-0.467 * * *$ & -0.243 & $-0.482 * * *$ & -0.613 \\
\hline & $(0.061)$ & $(0.365)$ & $(0.073)$ & $(0.496)$ & $(0.110)$ & $(0.420)$ \\
\hline \multirow[t]{2}{*}{ Rural Centre } & $0.475^{* * *}$ & 0.557 & $0.441^{* * *}$ & 0.552 & $0.538^{* * *}$ & 0.821 \\
\hline & $(0.098)$ & $(0.494)$ & $(0.138)$ & $(0.752)$ & $(0.152)$ & $(0.520)$ \\
\hline \multirow[t]{2}{*}{ Rural South } & $0.536 * * *$ & 0.832 & $0.535^{* * *}$ & 0.611 & $0.524 * * *$ & $1.450 * * *$ \\
\hline & $(0.098)$ & $(0.524)$ & $(0.142)$ & $(0.810)$ & $(0.145)$ & $(0.513)$ \\
\hline \multirow[t]{2}{*}{ Wet Season Dummy } & 0.027 & -0.096 & 0.053 & 0.051 & -0.043 & -0.144 \\
\hline & $(0.055)$ & $(0.177)$ & $(0.068)$ & $(0.262)$ & $(0.099)$ & $(0.225)$ \\
\hline \multirow[t]{2}{*}{ ADMARC Market Distance KM } & $0.0008 * * *$ & $0.0046 * * *$ & $0.0009 * * *$ & $0.0042^{* * *}$ & -0.0021 & 0.0047 \\
\hline & $(0.0003)$ & $(0.0010)$ & $(0.0003)$ & $(0.0012)$ & $(0.0030)$ & $(0.0077)$ \\
\hline \multirow[t]{2}{*}{ Distance to Asphalt Road KM } & -0.0005 & -0.0052 & 0.0006 & $-0.0115^{*}$ & -0.0020 & -0.0026 \\
\hline & $(0.0009)$ & $(0.0039)$ & $(0.0011)$ & $(0.0065)$ & $(0.0014)$ & $(0.0040)$ \\
\hline \multirow[t]{2}{*}{ Elevation } & 0.00010 & 0.00016 & 0.00015 & -0.00002 & 0.00005 & 0.00050 \\
\hline & $(0.00008)$ & $(0.00030)$ & $(0.00009)$ & $(0.00041)$ & $(0.00014)$ & $(0.00037)$ \\
\hline Biomass20 (m3/ha) & -0.001 & -0.003 & 0.001 & -0.015 & 0.001 & 0.000 \\
\hline & $(0.001)$ & $(0.003)$ & $(0.004)$ & $(0.017)$ & $(0.002)$ & $(0.004)$ \\
\hline Price of Maize Grain MK/Kg & -0.012 & -0.007 & -0.016 & -0.001 & -0.015 & -0.030 \\
\hline & $(0.010)$ & $(0.036)$ & $(0.013)$ & $(0.051)$ & $(0.020)$ & $(0.047)$ \\
\hline Recent illness/injury & $0.113^{* *}$ & 0.050 & 0.078 & -0.116 & $0.180^{* *}$ & $0.401 *$ \\
\hline & $(0.047)$ & $(0.179)$ & $(0.058)$ & $(0.233)$ & $(0.083)$ & $(0.234)$ \\
\hline Chronic illness & 0.030 & -0.078 & 0.122 & -0.013 & -0.199 & -0.264 \\
\hline & $(0.064)$ & $(0.208)$ & $(0.075)$ & $(0.291)$ & $(0.127)$ & $(0.317)$ \\
\hline Other Members Chronically Ill & $0.048^{*}$ & -0.061 & $0.055^{*}$ & -0.136 & 0.041 & 0.041 \\
\hline & $(0.026)$ & $(0.092)$ & $(0.032)$ & $(0.132)$ & $(0.047)$ & $(0.110)$ \\
\hline
\end{tabular}




\begin{tabular}{|l|l|l|l|l|l|l|}
\hline Substitute for collected fuelwood & $-0.395^{* * *}$ & & $-0.354^{* * *}$ & & $-0.614^{* * *}$ & \\
\hline & $(0.072)$ & & $(0.080)$ & & $(0.176)$ & \\
\hline Constant & $-1.454^{* * *}$ & -1.408 & $-1.400^{* * *}$ & -0.766 & $-1.487 * * *$ & -3.020 \\
\hline & $(0.250)$ & $(1.837)$ & $(0.314)$ & $(2.577)$ & $(0.452)$ & $(1.966)$ \\
\hline Observations & 11169 & 11169 & 7336 & 7336 & 3833 & 3833 \\
\hline Inverse Mills Ratio & & 1.041 & & 0.693 & & $1.972 * *$ \\
\hline & & $(0.801)$ & & $(1.110)$ & & $(0.813)$ \\
\hline
\end{tabular}

Standard errors in parentheses * significant at $10 \%$; ${ }^{* *}$ significant at $5 \% ; * * *$ significant at $1 \%$ 
Appendix Table 3: Labor allocation hours for household agriculture by men 10 years and older

\begin{tabular}{|c|c|c|c|}
\hline & $(1)$ & $(2)$ & (3) \\
\hline & Overall & Less Biomass Areas & More Biomass Areas \\
\hline \multirow[t]{2}{*}{ Age in years } & $0.113^{* * *}$ & $0.115^{* * *}$ & $0.116^{* * *}$ \\
\hline & $(0.010)$ & $(0.013)$ & $(0.017)$ \\
\hline \multirow[t]{2}{*}{ Age Square } & $-0.001 * * *$ & $-0.001 * * *$ & $-0.001 * * *$ \\
\hline & $(0.000)$ & $(0.000)$ & $(0.000)$ \\
\hline \multirow[t]{2}{*}{ Head Education: Snr. Prim or more } & $-0.164 * * *$ & $-0.166 * *$ & -0.137 \\
\hline & $(0.056)$ & $(0.069)$ & $(0.093)$ \\
\hline \multirow[t]{2}{*}{ HH Size } & $-0.021^{* *}$ & $-0.032 * *$ & $-0.031 *$ \\
\hline & $(0.011)$ & $(0.013)$ & $(0.019)$ \\
\hline \multirow[t]{2}{*}{ Real Value of Assets '000 } & $-0.003 * * *$ & $-0.003 * * *$ & $-0.004 * * *$ \\
\hline & $(0.001)$ & $(0.001)$ & $(0.001)$ \\
\hline \multirow[t]{2}{*}{ Wet Season \& Wet Area Interaction } & $0.252 * * *$ & $0.259 * * *$ & $0.274 * * *$ \\
\hline & $(0.039)$ & $(0.045)$ & $(0.077)$ \\
\hline \multirow[t]{2}{*}{ Dry Season and Dimba Area Interaction } & $1.063 * * *$ & $0.982 * * *$ & $1.040 * * *$ \\
\hline & $(0.132)$ & $(0.159)$ & $(0.235)$ \\
\hline \multirow[t]{2}{*}{ Total hectares of land uncultivated } & 0.030 & $0.139 *$ & $-0.121 *$ \\
\hline & $(0.047)$ & $(0.072)$ & $(0.062)$ \\
\hline \multirow[t]{2}{*}{ Total hectares of trees } & -0.233 & $-1.166^{*}$ & $1.047^{*}$ \\
\hline & $(0.463)$ & $(0.692)$ & $(0.607)$ \\
\hline \multirow[t]{2}{*}{ Predicted Real Wage for Women } & $-0.005 * * *$ & $-0.005 * * *$ & $-0.004 * * *$ \\
\hline & $(0.001)$ & $(0.001)$ & $(0.001)$ \\
\hline \multirow[t]{2}{*}{ Number of $<5 y r$ children } & -0.114 & -0.149 & -0.004 \\
\hline & $(0.141)$ & $(0.168)$ & $(0.259)$ \\
\hline \multirow[t]{2}{*}{ Married } & $0.453 * * *$ & $0.434 * * *$ & $0.448 * * *$ \\
\hline & $(0.079)$ & $(0.098)$ & $(0.131)$ \\
\hline \multirow[t]{2}{*}{ Rural Centre } & $-0.530 * * *$ & $-0.767 * * *$ & -0.038 \\
\hline & $(0.097)$ & $(0.132)$ & $(0.151)$ \\
\hline \multirow[t]{2}{*}{ Rural South } & $-0.487 * * *$ & $-0.684 * * *$ & $-0.380 * * *$ \\
\hline & $(0.095)$ & $(0.135)$ & $(0.138)$ \\
\hline \multirow[t]{2}{*}{ Wet Season Dummy } & $0.740 * * *$ & $0.616^{* * *}$ & $0.950 * * *$ \\
\hline & $(0.066)$ & $(0.082)$ & $(0.114)$ \\
\hline \multirow[t]{2}{*}{ ADMARC Market Distance KM } & $0.002^{* * *}$ & $0.001^{* * *}$ & $0.018 * * *$ \\
\hline & $(0.001)$ & $(0.001)$ & $(0.003)$ \\
\hline \multirow[t]{2}{*}{ Distance to Asphalt Road KM } & $0.009 * * *$ & $0.005 * * *$ & $0.011 * * *$ \\
\hline & $(0.001)$ & $(0.001)$ & $(0.001)$ \\
\hline \multirow[t]{2}{*}{ Elevation } & 0.000 & -0.000 & 0.000 \\
\hline & $(0.000)$ & $(0.000)$ & $(0.000)$ \\
\hline \multirow[t]{2}{*}{ Biomass20 (m3/ha) } & $-0.006 * * *$ & 0.004 & $-0.004 * *$ \\
\hline & $(0.001)$ & $(0.006)$ & $(0.002)$ \\
\hline \multirow[t]{2}{*}{ Price of Maize Grain MK/Kg } & -0.001 & $0.056 * * *$ & $-0.088 * * *$ \\
\hline & $(0.013)$ & $(0.017)$ & $(0.023)$ \\
\hline \multirow{2}{*}{ Recent illness/injury } & $-0.244 * * *$ & $-0.282 * * *$ & $-0.189 *$ \\
\hline & $(0.060)$ & $(0.075)$ & $(0.098)$ \\
\hline Chronic illness & 0.107 & $0.205 * *$ & $-0.232 *$ \\
\hline & $(0.083)$ & $(0.102)$ & $(0.141)$ \\
\hline Other Members Chronically Ill & $-0.075 * *$ & -0.068 & $-0.161 * * *$ \\
\hline & $(0.035)$ & $(0.043)$ & $(0.059)$ \\
\hline Productive Assets Index & $11.334 * * *$ & $9.565 * * *$ & $19.574 * * *$ \\
\hline & $(0.854)$ & $(0.974)$ & (1.828) \\
\hline Constant & -0.193 & $-0.644 *$ & 0.080 \\
\hline & $(0.302)$ & $(0.381)$ & $(0.507)$ \\
\hline Observations & 10935 & 7186 & 3749 \\
\hline
\end{tabular}

Standard errors in parentheses * significant at 10\%; ** significant at 5\%; *** significant at $1 \%$ 